\title{
IMMIGRATION POLICY INDEX
}

\section{Dmytro Vikhrov}

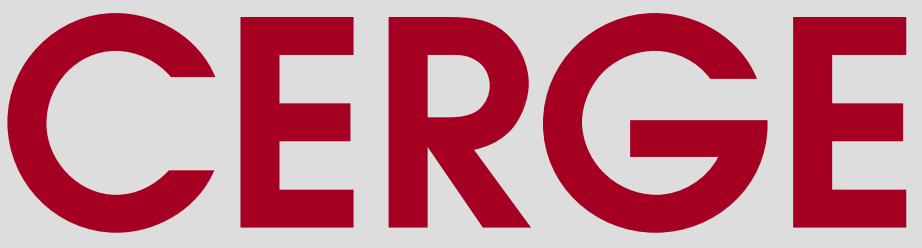

\section{Charles University}

Centerfor Economic Research and Graduate Education

Academy of Sciences of the Czech Republic

Economic Institute 


\title{
Working Paper Series $\quad 523$ (ISSN 1211-3298)
}

\section{Immigration Policy Index}

\author{
Dmytro Vikhrov
}

CERGE-EI

Prague, December 2014 
ISBN 978-80-7343-328-4 (Univerzita Karlova. Centrum pro ekonomický výzkum a doktorské studium)

ISBN 978-80-7344-320-7 (Akademie věd České republiky. Národohospodářský ústav) 


\title{
Immigration Policy Index
}

\author{
Dmytro Vikhrov* \\ CERGE-EI
}

\begin{abstract}
I construct an immigration policy index which is heterogeneous across destinationorigin country pairs and variant over time. This index is based on three types of entry visa restrictions: visa required, visa not required for short stays and visa not required at all. When estimated in levels, visa exempt country pairs account for around $15 \%$ more migrants than their counterfactual. I show that the effects of migration determinants vary by the type of visa restrictions. Further, I identify country pairs which changed their visa regime during 2000-2010 and find that the weakening of visa policy is associated with a $10 \%$ increase in migrant stocks and a significant shift toward male and less skilled migration from policy affected source countries. In contrast, the tightening of visa policy is not related to a significant change in migrant stocks, their gender or skill composition.
\end{abstract}

Keywords: immigration policy; visa; difference-in-difference estimation; policy quasi-experiment; group heterogeneity; diaspora effect

JEL Classification: F22; K37; F66; R23

\footnotetext{
${ }^{*}$ I am grateful to Byeongju Jeong, Jan Kmenta, Nikolas Mittag, Randy Filer, Alexei Savvateev, and Sherzod Tashpulatov for helpful comments. I am thankful to Ladislav Bednář from ČSA for kindly providing access to data. I benefited from discussions with summer school lecturers at EUI in Florence (2012), University of Rethymnon (2013), University of Milan (2013), Parthenope University of Naples (2014), and MPI in Jena (2014). The earlier version of the paper was published as MPC Analytical and Synthetic Note 2013/02. E-mail: dvikhrov@cerge-ei.cz

${ }^{\dagger}$ A joint workplace of the Center for Economic Research and Graduate Education, Charles University, and the Economics Institute of the Academy of Sciences of the Czech Republic Address: CERGE-EI, P.O. Box 882, Politických vězňů 7, Prague 11121, Czech Republic
} 


\begin{abstract}
Abstrakt
Konstruuji index imigrační politiky, který je heterogenní v rámci párů cílové země a země pưvodu a je proměnný v čase. Tento index je založen na třech typech vízových omezení vstupu: vízum je vyžadováno, vízum není vyžadováno pro krátkodobé pobyty a vízum se nevyžaduje vůbec. Když je model odhadnut v úrovních, neexistence vízové povinnosti u daného páru země představuje přibližně $15 \%$ nárůst počtu přistěhovalců oproti kontrafaktuálnímu scénáři. Ukazuji, že dopady determinantů migrace se liší podle druhu vízové povinnosti. Dále jsem se identifikoval dvojice zemí, které změnily svůj vízový režim během období 2000-2010, a zjistil, že oslabení vízové politiky je spojeno se zvýšením populace přistěhovalců o $10 \%$ a signifikantním posunem směrem k mužské a méně kvalifikované migraci ze zemí ovlivněných změnou vízové politiky. Naopak, zprrísnění vízové politiky nesouvisí se signifikantní změnou v populaci migranti̊, jejich pohlavím nebo skladbou dovedností.
\end{abstract}




\section{Introduction}

Immigration policy is one of the key determinants of international migration. It consists of rules which govern the admission of foreigners, their access to the labor market, healthcare, welfare, voting, and family reunion. This complex set of rules also means that it is difficult to measure immigration policy empirically and calls for more research in the area.

In this paper I suggest using entry visa rules to measure the tightness of immigration policy. Entry restrictions affect the amount of migrants through information and feasibility channels. In the absence of any visa barriers between two countries, workers can move freely, disseminating information about employment opportunities abroad (information channel). In response to a wage gap, workers take up jobs abroad, because they are not restricted in mobility by visas (feasibility channel).

In the presence of visa restrictions, workers' mobility and access to information is restricted, because they need to apply for an entry clearance (visa) prior to traveling. In many cases a positive outcome of an application is not guaranteed, because job-seeking alone is not a sufficient reason to obtain a visa. Even though information on better paying jobs abroad might be generally available, workers cannot take them due to travel and employment restrictions. All else being equal, firms might be reluctant to hire migrant workers, because of extra paperwork.

The immigration policy index is constructed for all countries and territories in the world as of March 1998 and November 2009. This index is heterogeneous across destination and origin countries as well as over time. I find that country pairs with simplified entry restrictions (visa partially required or visa not required) account for about $15 \%$ more migrants than pairs with visa required status. Also, these migrants are more likely to be males and less educated.

I further set up a quasi-policy experiment which tracks down policy shifters for which immigration policy changed between March 1998 and November 2009. I find that after visas were abolished, the stocks of migrants in affected country pairs increased $10 \%$ relative to their counterfactual. The increase was predominantly in male and less educated migration. In contrast, the introduction of visas was not associated with a statistically 
significant change in the stock of migrants, their gender or education composition for the period considered.

Although most studies surveyed do somehow acknowledge the presence of immigration policy, more research needs to address its complex nature. For the succinctness of exposition I summarize key studies in the literature in Table B.1. I only review papers that analyze country level aggregate data. In such studies a unit of observation is a destination-origin country pair (dyad) in year $t$.

The determinants of international migration can be broken down into four major groups: economic incentives, demographic factors, linguistic and cultural proximity, and institutional factors. While the first three groups have been extensively studied in the literature, immigration policy remains under-researched mainly due to the lack of comparable cross-country data. The role of these factors is also studied in wider literature on the determinants of international trade (Head and Mayer, 2015) and economic growth (Alesina et al., 2003).

The idea of using visa restrictions to quantify institutional barriers to mobility is not new. Hobolth (2014) constructs a European visa database for whether a sending country needs a visa to the EU destinations. Glaesser and Kesler (2013) consider visa restriction as an obstacle to tourism and construct an aggregate index of visa openness for each country. Based on these data, Neumayer (2010) estimates that the presence of visas is associated with a 52-63\% reduction in tourism related travel. Using data from expert surveys, Huddleston et al. (2011) creates 7 aggregate indexes that compare the national policies of 31 developed destinations on family reunion, access to labor market, education, nationality, and voting.

Since most authors analyze immigration into the OECD countries, they include Schengen or EU dummies. Grogger and Hanson (2011) and González and Miles-Touya (2014) also add visa waiver dummies. To control for the tightness and skill selectivity of immigration policies, Beine et al. (2011), Grogger and Hanson (2011), and Docquier et al. (2012) use the shares of refugees and asylees in stocks. Mayda (2010) and Ortega and Peri (2013) follow a different approach. Based on destination country legislation, they construct aggregate country-specific indexes to proxy for the tightness of immigration policies. Palmer and Pytlikova (2013) and Kahanec et al. (2014) develop an index of 
labor market access laws for migrants within the EU.

I contribute to the literature in two ways. First, I expand the classification of visa waivers to three categories: visa required, visa partially required and visa not required. A dummy variable from existing studies becomes a categorical variable in this study, thus generating more variation. Second, using IATA (1998) and IATA (2009) data, I create this categorical variable for all countries and territories in the world at two points in time: March 1998 and November 2009. This enables me to identify policy shifters and track changes in the stocks of migrants, their gender and skill composition relative to non-shifters.

The emphasis on world migration extends many existing studies which mainly emphasize migration into the developed OECD countries. Belot and Ederveen (2012) analyze migration only within the developed world, claiming that the mechanism behind North $\leftrightarrow$ North migration is somehow different. However, the UN (2011) estimate that North $\leftrightarrow$ North migration accounts for $25 \%$ of world migration, whereas migration within the developing countries of the South alone amounts to $35 \%$ of the world total. By analysing world migration data, I learn about the data generating mechanism behind migration for all countries, not only the developed ones.

The paper is structured as follows. I first construct a simple theoretical model of the determinants of migration. Sections 3 and 4 describe the construction of the index and policy quasi-experiment. Next, I describe the data used, set up and estimate the empirical model, check its robustness and discuss the estimation results.

\section{The model of the determinants of migration}

There is an active debate in the literature as to whether the utility function of a representative worker is linear or log-linear in wage gain from emigration. Suppose a worker's wage at origin is 100 units and his wage at destination is 120 units. For a linear utility function, the net gain from emigration (assuming zero migration costs) is 20 units. For a log-linear utility, this increase is $20 \%$ of the current wage. A worker with a linear utility function cares about an absolute wage gain, whereas a worker with a log-linear function cares about the magnitude of wage increase relative to the current level. Grogger and 
Hanson (2011) elaborate on differences between the se two functional forms.

In line with the debate, I develop two versions of the model which differ in their approach to individual migration costs. In model one the costs are expressed in terms of units and in version two they are modeled in terms of time.

\subsection{Version one: additive migration costs}

A developed country A with population $N^{A}$ receives migrants from a developing country B with population $N^{B}$. In each country the population consists of skilled and unskilled workers, denoted by $H$ and $L$, with respective shares in population $\alpha^{A}$ and $\alpha^{B}$. Wages are assumed to be exogenous and satisfy the following inequality:

$$
w_{H}^{A}>w_{H}^{B}>w_{L}^{A}>w_{L}^{B} .
$$

Worker $k$ emigrates if inequality (2) holds, and stays otherwise:

$$
w_{s}^{A}-w_{s}^{B}>C_{k s}
$$

where $C_{k s}$ stands for broadly defined migration costs of an individual $k$ of skill type $s$, $s=L, H$. The costs are assumed to have the following additive structure:

$$
C_{k s}=D-S-L-H-I+\nu_{k s},
$$

where $D$ is distance between countries; $S$ is the stock of migrants from country B in country A; $L$ measures language similarity between $\mathrm{A}$ and $\mathrm{B} ; H$ measures historic and cultural proximity between A and B; I measures the tightness of immigration policy of country A with respect to B; $\nu_{i s}$ is a random variable. Since there are only two countries, I omit country superscripts.

Under the assumption of uniform distribution, $\nu_{i s} \sim U[0,1]$, the stock of migrants of skill $s, M_{s}$, expressed as the share of $N^{B}$ is:

$$
\begin{aligned}
\frac{M_{s}}{N^{B}} & =\operatorname{Prob}\left(w_{s}^{A}-w_{s}^{B}-D+S+L+H+I>\nu_{k s}\right)= \\
& =w_{s}^{A}-w_{s}^{B}-D+S+L+H+I .
\end{aligned}
$$


Since equation (4) holds for both skill types, the total stock is:

$$
\frac{M_{L}+M_{H}}{N^{B}}=w_{L}^{A}-w_{L}^{B}+w_{H}^{A}-w_{H}^{B}-2 D+2 S+2 L+2 H+2 I .
$$

Wages $w_{s}^{A}$ and $w_{s}^{B}$ are not observed in data, but they can be inferred from average wages, the Gini index and average years of schooling through equations (18) and (19) derived in Appendix A.

\subsection{Version two: multiplicative migration costs}

The setup is the same as in version one, except individual migration costs $C_{k s}$ are in multiplicative form. The decision rule (2) thus becomes:

$$
\frac{w_{s}^{A}}{C_{k s}}>w_{s}^{B},
$$

where $C_{k s}$ is a non-negative random variable which plays the role of an individual discount factor. For workers with low $C_{k s}$ the effective wage abroad, $\frac{w_{s}^{A}}{C_{i s}}$, exceeds the effective wage of workers with high $C_{k s}$. All else being equal, the effective wage favors individuals who speak foreign languages, have relatives living abroad and quickly adjust to new living conditions.

Individual costs are assumed to have multiplicative form:

$$
C_{k s}=\frac{D}{S \cdot L \cdot H \cdot I} \cdot \nu_{k s}
$$

where $D, S, L$ and $I$ are positive continuous variables defined in version one. $\nu_{k s}$ is a random variable from the exponential family of distribution functions, $F(\nu)=\alpha(\nu)^{\rho}$. Parameters $\alpha$ and $\rho$ are jointly determined so that $F(\cdot)$ satisfies the definition of a distribution function.

The stock of migrant workers of skill type $s$ is:

$$
\frac{M_{s}}{N^{B}}=\operatorname{Prob}\left(\frac{w_{s}^{A} \cdot S \cdot L \cdot H \cdot I}{w_{s}^{B} \cdot D}>\nu_{k s}\right)=\alpha\left(\frac{w_{s}^{A} \cdot S \cdot L \cdot H \cdot I}{w_{s}^{B} \cdot D}\right)^{\rho} .
$$


Taking the logarithm of both sides I obtain:

$$
\ln \frac{M_{s}}{N^{B}}=\ln \alpha+\rho\left(\ln w_{s}^{A}+\ln S+\ln L+\ln H+\ln I-\ln w_{s}^{B}-\ln D\right) .
$$

In equation (9) all variables are in logarithms, whereas in equation (5) the variables are in levels. In order to choose between these two competing equations, I will apply the PE test (Kmenta, 1990, pp. 521-522) in Section 6.

\section{$3 \quad$ Policy index design}

The purpose of constructing the immigration policy index is to rank in a consistent manner the tightness of entry rules for all countries and territories in the world. The simplification of entry rules reduces institutional barriers, facilitates better job search and lowers mobility costs, allowing people to respond to economic incentives more elastically. It is interesting to estimate the extent to which these entry restrictions affect migrant stocks, their gender and skill composition. Empirical studies that do not account for immigration policy might produce unreliable estimates due to omitted variable bias.

Imagine that by default every sovereign country demands a visa from arriving foreign nationals. At the same time every destination has a number of source countries with which it has friendly relations and thus simplified visa regimes. Governed by data, I distinguish three major categories of entry rules: "visa is required," "visa is not required for a stay shorter than $n$ days," and "visa is not required". Examples of country pairs in each category are given in Table B.3. ${ }^{1}$

The default state "visa is required" is when a person prior to commencing journey has to contact the nearest embassy of a destination country (or other country liable to issues visas on its behalf), submit a visa application in person, online or by ordinary mail. Usually a letter of invitation or sponsorship from a hosting institution, company or family at destination is required. This process is time consuming and in many instances it is advised to start the application process at least a month prior to the planned travel

\footnotetext{
${ }^{1} \mathrm{~A}$ traveller is assumed to hold a normal passport (not consular, diplomatic, service, business or special passport), travel alone as a tourist for a very short stay from a country of origin and hold no valid visas to other destinations.
} 
date. Afghanistan, Myanmar, and Turkmenistan are examples of countries that demand visas from every nationality.

The category "visa is not required for stays shorter than $n$ days," also referred to in this text as "visa is partially required," is when a host country allows certain nationals to enter without a visa for stays not exceeding a certain number of days. For 2010 this limit ranges from 7 days for Togo $\leftarrow$ New Zealand (tourists in Togo from New Zealand) to 365 days for Palau $\leftarrow$ Micronesia. The two most frequently observed durations are 90 and 30 days. Often the duration of an allowed visa free stay varies according to the purpose of travel: tourist or family related stays are on average allowed to last longer than business related stays. Often a traveller is required to hold a return ticket, sufficient funds for the duration of stay and produce evidence of the reservation of accommodation. This category also combines countries that issue visas upon arrival for a fee.

The US visa waiver and Australia ETA and eVisitor online visas application programs fall into this category. These programs allow certain nationals to apply for travel authorisation online and avoid lengthy application procedures and enhanced security checks.

I group allowed durations of stay and provide examples of country pairs in each group in Table B.4. I also regress $\ln \left(\right.$ stock $\left._{i j t}\right)$ on a set of duration group dummy variables to learn if longer duration of stay can be associated with larger migrant stock. Indeed this is the case as the estimates in Table 1 suggest.

Table 1: Differences in the means of $\ln \left(\right.$ stock $\left._{i j t}\right)$ by the duration of visa free stay, pooled sample.

\begin{tabular}{|c|c|c|}
\hline Variable & Estimate & S.E. \\
\hline$[3,30)$ days & \multicolumn{2}{|c|}{ base category } \\
\hline 30 and 31 days & 0.332 & $(0.58)$ \\
\hline$[45,90]$ days & $1.106^{* *}$ & $(0.51)$ \\
\hline$[120,365]$ days & $1.968 * * *$ & $(0.76)$ \\
\hline y10 & -0.041 & $(0.14)$ \\
\hline cons & $4.573^{* * *}$ & $(0.49)$ \\
\hline
\end{tabular}

The least restrictive entry category is "visa is not required," when no limit is imposed on the duration or purpose of stay. Quite often visa free travel is associated with 
simplified access to the local labor market. For 2010 this regime is established between the USA $\leftrightarrow$ Canada, Australia $\leftrightarrow$ New Zealand, EEA countries, most republics of the former Soviet Union, Gulf Cooperation Council countries, Algeria $\leftrightarrow$ Morocco $\leftrightarrow$ Tunisia and Uganda $\leftrightarrow$ Eritrea $\leftrightarrow$ Kenya, to mention some of the most prominent examples. The existence of a visa free regime is associated with regional integration, enhanced bilateral trade and development programs.

A note should be made on the classification of countries' overseas territories. ${ }^{2}$ From the perspective of a destination country, mainland and overseas territories are considered separate items, because in most cases such territories share different immigration policies than their mainland countries. For example, Puerto Rico and the US Virgin Islands' visa waiver programs are less restrictive than the US mainland program. Many of the UK overseas territories are popular tourist destinations and have more welcoming immigration policies than the UK mainland. For example, the Turks and Caicos Islands and Bermuda issue visas upon arrival for up to one month and six months, respectively, to most nationalities. French Polynesia allows only a 90 day visa waiver for the EU countries, compared to visa free entrance granted by mainland France.

From the perspective of a sending country, overseas territories and the mainland share a similar, if not the same, passport and are thus considered one sending country. For example, for most destinations in the world a British passport, which is shared by the citizens of the UK and the British overseas territories, grants equal immigration rights irrespective of the endorsement in a passport. ${ }^{3}$ Also, for most destinations equal rights hold for passports issued by source country mainland and overseas territories.

An apparent advantage of the constructed index is that it provides variation across country pairs, over time and can be constructed for all country pairs. This is a relative improvement over the indexes of Ortega and Peri (2013), Mayda (2010) and Palmer and Pytlikova (2013). The visa index also has clear intuitive design and straightforward interpretation in regression analysis. This extends the analyzes of Docquier et al. (2012) and Grogger and Hanson (2011) in a way that the shares of females or refugees in stocks

\footnotetext{
${ }^{2}$ For the correctness of terminology, each country has its own term for overseas territories: unincorporated territory (US), constituent country (the Netherlands), overseas department / collectivity/ sovereignty (France) and autonomous country (Denmark).

${ }^{3}$ Possible endorsements are: British Citizen, British Overseas Territories Citizen, British national (overseas), British Overseas Citizen, British Protected Person and British Subject.
} 
are the outcome of demand and supply equations. Individuals decide to apply for entry clearance and then a destination country decides whether to grant an entry permit.

A disadvantage of the created index is the ignorance of migrants' rights to employment, access to various benefits, healthcare, which are not captured by entry visa rules. However, it normally holds that less restrictive entry rules are associated with more rights granted to migrants.

\section{Policy quasi-experiment setup}

I compile the immigration policy index for March 1998 and November 2009. The stock data are observed for the middle of 2000 and 2010. The purpose of this policy quasiexperiment is to identify country pairs for which the policy index was changed during 2000-2010 and investigate how these changes reflected on the stock of migrants and their composition relative to country pairs with an unchanged policy index.

There are two types of policy changes: policy weakening (up-shifters) and policy tightening (down-shifters). The treatment group consists of shifter country pairs and the control group is composed of non-shifter pairs. The treatment effects are heterogeneous, because there are three types of up-shifter country pairs and the same number of downshifter pairs. These types are explained further below.

There are two underlying hypotheses to be tested. Hypothesis one states that the introduction of entry visas decreases the amount of migrants from affected source countries. According to hypothesis two, the abolition of visas increases the stocks of migrants from the countries in question. The span of 10 years is assumed to provide sufficient time for policy change to take effect. Finally, it is worth investigating how the visa rules affect the gender and skill composition of migrant stocks. Previous studies have documented that stricter immigration policies are associated with more skilled migrants (Grogger and Hanson, 2011; Beine et al., 2011).

Table 2 shows that for about $19 \%$ of country pairs the visa regime was changed between 2000 and 2010. Visa policy was weakened for $13.5 \%$ and tightened for $5.5 \%$ of country pairs. The weakening of policy means one of the following two statements:

1. visa required regime was changed to visa partially required or visa not required; 
2. visa partially required was changed to visa not required.

Symmetrically, the tightening of visa policy implies one of the following two statements:

1. visa partially required was changed to visa required;

2. visa not required was changed to visa partially required or visa required.

Table 2: Tabulation of policy changes in 2000-2010.

\begin{tabular}{|c|c|c|c|c|c|}
\hline & & $\begin{array}{c}\text { Visa } \\
\text { required }\end{array}$ & $\begin{array}{l}2010 \\
\text { Visa partially } \\
\text { required }\end{array}$ & $\begin{array}{l}\text { Visa not } \\
\text { required }\end{array}$ & total \\
\hline \multirow{4}{*}{2000} & Visa required & 24722 & 4741 & 200 & 29663 \\
\hline & Visa partially required & 1914 & 8623 & 712 & 11249 \\
\hline & Visa not required & 113 & 256 & 549 & 918 \\
\hline & Total & 26749 & 13620 & 1461 & 41830 \\
\hline
\end{tabular}

Data in Table 2 show that all types of policy changes took place during 2000-2010. The most frequent policy change is the move from visa required to visa partially required (4741 country pairs). This includes the extension of the US visa waiver program, ETA and eVisitor programs in Australia and Federal skilled worker program in Canada. The EU granted partial visa waivers to Bolivia, Costa Rica, and most of the British overseas territories.

For most countries there is a clear tendency to become more open to immigration. Since I have 217-by-202 matrix of country pairs over two points in time, it is difficult to summarize the dynamics of immigration policy for each country pair without aggregation. For each destination country $i$ and $t=\{2000,2010\}$ I compute $\alpha(i, t, v p)$, the share of origin countries in each visa category $v p, v p=\{0,1,2\}$. Obviously, $\sum_{v p=0}^{2} \alpha(i, t, v p)=$ $1 \forall i$ and $t$. For given $i, d(i, v p)$ denotes the time change of each share in group $v p$, $d(i, v p)=\alpha(i, t=2010, v p)-\alpha(i, t=2000, v p)$, leading to the following identity:

$$
d(i, v p=0)+d(i, v p=2)=-d(i, v p=1) .
$$

Since the differenced shares are linearly dependent (equation (10)), it is sufficient to consider only two arbitrary shares. In Figure 1 , I plot $-d(i, v p=0)$ against $d(i, v p=2)$. 
In this figure, moving right along the horizontal axis means that a destination country weakened its visa policy by expanding the visa not required category and narrowing the visa required and/or visa partially required categories. Moving up the vertical axis means that a destination country weakened its visa policy by shrinking the visa required category and expanding the visa partially required and/or visa not required categories.

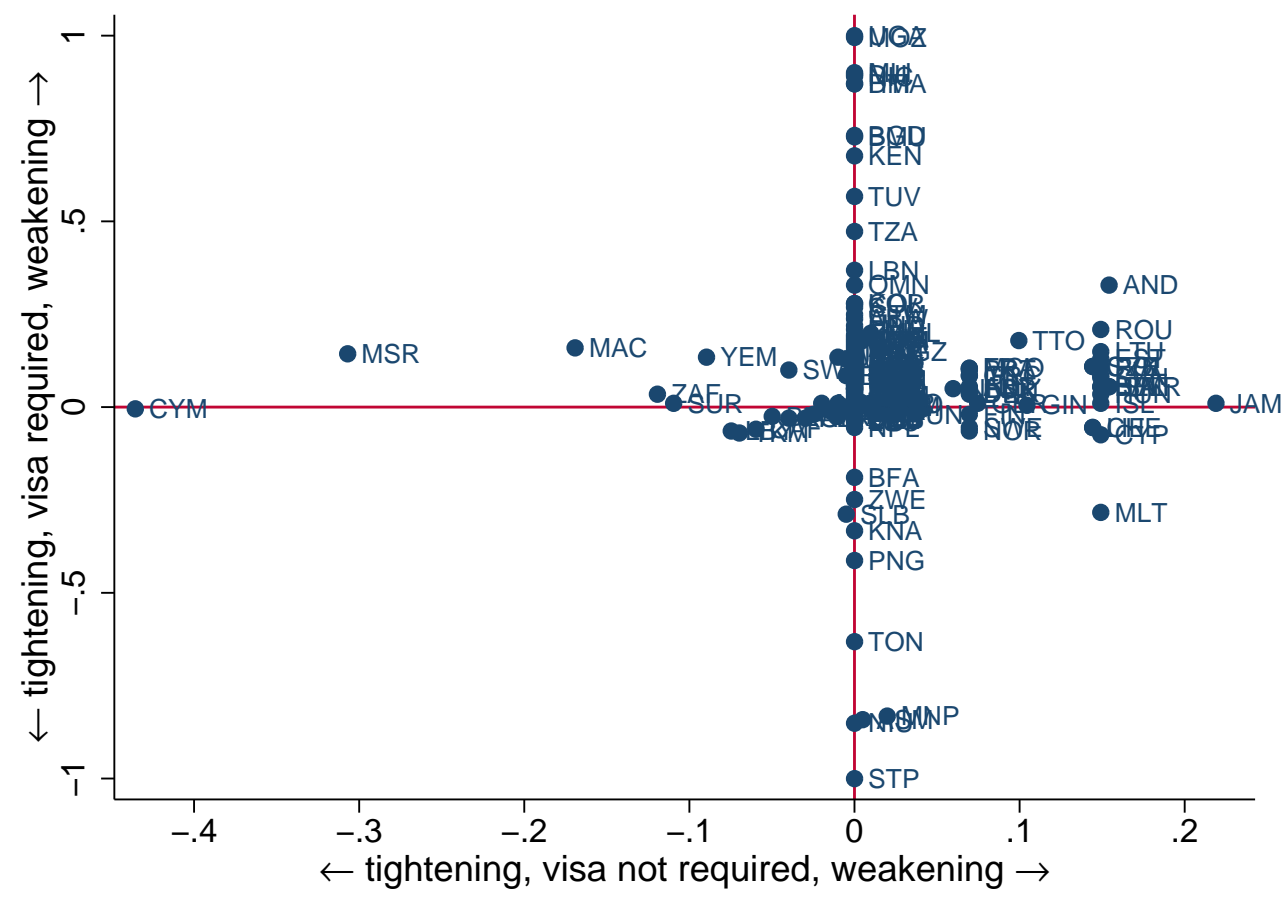

Figure 1: Scatter plot of policy changes in 2000-2010.

All visa policy changes can be structured as follows. Along the horizontal axis in Figure 1 are located countries that expanded or contracted the visa not required category by reshuffling between the visa required or visa partially required categories. Jamaica, Romania and Andorra expanded the visa not required and narrowed the visa required categories.

Along the vertical axis are the countries that altered the visa required category by expanding or narrowing the visa not required or visa partially required categories. Oman, Lebanon, and Kenya became more liberal by narrowing visa required and expanding visa partially required categories. The cluster of countries in the middle did not change their entry policies. 


\section{Data description}

\subsection{Construction of variables}

This section rationalizes data sources used and explains the construction of variables. Table B.2 summarizes the definitions of variables and data sources.

Visa policy. Raw data for the visa policy dummies come from IATA (1998) and IATA (2009). Each of these two sources is a paper-back manual with various information for each country and territory in the world. For 1998 and 2009 I create a matrix of destination-origin country pairs. ${ }^{4}$ Due to missing information on Georgia, Armenia, Moldova, Tajikistan and Congo (Brazzaville) in 1998, these entries are excluded from estimation in both years.

Migrant stocks. The decision to use stock but not flow data is motivated by wider country coverage. Flows and stocks are linked through the law of motion. Assuming zero stocks at $t=0$, stocks at $t+1$ are total flows until $t$ adjusted for the rates of outmigration, naturalization and death. Changes in entry visas should be reflected in flow data immediately and in stock data with a sort delay.

There are several sources of comprehensive macro level migration data. OECD (2013), UN (2013) and Özden et al. (2011) provide stocks disaggregated by gender. Of these three, OECD (2013) is the most frequently cited source, however it contains information only on the OECD destinations. Artuc et al. (2013), Defoort (2008) and Brücker et al. (2013) supply stock data by educational attainments for selected destinations. I use UN (2013) and Brücker et al. (2013) data, because they provide the most up-to-date and extensive geographical coverage at the time of writing this paper.

Wage data. I impute unskilled and skilled wages from GDP per capita (Feenstra et al., 2013), the Gini index (Solt, 2014) and years of schooling data (Barro and Lee, 2013) using equations (18) and (19) in Appendix A. Grogger and Hanson (2011) mention a similar method as one possible imputation technique.

Cultural proximity. I use all six dummy variables from Head et al. (2010) data to proxy for cultural and historic proximity of a country pair. Two apparent issues arise

\footnotetext{
${ }^{4}$ The created matrix is not symmetric due to the different treatment of dependent territories as receiving and sending countries.
} 
here. First, some of them are highly correlated, potentially leading to multicollinearity. Second, I am interested in the overall degree of cultural and historic similarity, irrespective of whether this comes from a colonial past, having a common coloniser or being in the same country. To address both issues, I perform principal component analysis, which reduces the dimensionality to three components: ${ }^{5}$

$$
\begin{aligned}
& p c_{1}=0.06 \cdot D_{\text {contig }}+0.64 \cdot D_{\text {colony }}-0.05 \cdot D_{\text {comcol }}+0.39 \cdot D_{\text {curcol }}+0.66 \cdot D_{\text {col } 45}+0.04 \cdot D_{\text {smctry }}, \\
& p c_{2}=0.57 \cdot D_{\text {contig }}+0 \cdot D_{\text {colony }}+0.49 \cdot D_{\text {comcol }}-0.03 \cdot D_{\text {curcol }}-0.04 \cdot D_{\text {col } 45}+0.65 \cdot D_{\text {smctry }}, \\
& p c_{3}=-0.54 \cdot D_{\text {contig }}+0 \cdot D_{\text {colony }}+0.72 \cdot D_{\text {comcol }}+0.43 \cdot D_{\text {curcol }}-0.03 \cdot D_{\text {col } 45}-0.05 \cdot D_{\text {smctry }},
\end{aligned}
$$

where $D_{\text {contig }}$ is a dummy variable for sharing a common border, $D_{\text {colony }}$ stands for the same colony, $D_{\text {comcol }}$ denotes a common colonizer, $D_{\text {curcol }}$ is a dummy for currently being in a colony, $D_{\text {col45 }}$ is a binary variable for a colony after 1945 and $D_{\text {smctry }}$ is a dummy variable for the same country.

These components explain more than $70 \%$ of variation in the original six variables. Component $p c_{1}$ assigns large weight to being in a colony. Component $p c_{2}$ emphasizes sharing the same border, being in the same country or sharing a common colonizer. Finally, component $p c_{3}$ favors contiguity, common colonizer, and current colony.

Language similarity. Using Ethnologue database (Lewis et al., 2013) I tabulate the 3 most frequently spoken languages for each country. ${ }^{6}$ In some cases this includes official, regional and minority language (including those spoken by migrants). Then, I created a dummy variable that equals 1 if a country pair shares at lest one common spoken language. Out of $217 \times 202$ country dyads, $17.27 \%$ share a common language.

This approach slightly differs from existing studies. Head et al. (2010) create a widely circulated dataset with a dummy variable for a common official language. In many cases,

\footnotetext{
${ }^{5}$ Similar types of aggregation are frequent in cross-country studies: Melitz and Toubal (2014) create an aggregate index of a common language, Alesina et al. (2003) build measures of within country fractionalization based on the degree of linguistic, ethnic, and religious diversity of a country. In studies based on microdata, Vyas and Kumaranayake (2006) construct an aggregate index of individual socio-economic status, and Greene (2012) (example 4.12 on p. 93) constructs an index of online movie popularity.

${ }^{6}$ Ethnologue database alongside with CIA factbook, Encyclopedia Britannica and Wikipedia are also cited by Melitz and Toubal (2014), Belot and Ederveen (2012), Head and Mayer, 2015 and Alesina et al. (2003).
} 
this does not capture regional language variation within a country. ${ }^{7}$ To address the issue, Melitz and Toubal (2014) create three more variables: common spoken language and common native language (measured as the shares of speakers in a country pair, based on microdata) and linguistic proximity (based on assignment to branches in a language tree or the degree of similarity of a set of words).

\subsection{Analysis of means of stocks}

The collected dataset is a short panel of 217 destination and 202 origin countries and territories over two years (2000 and 2010). The unit of observation is a destination-origin country pair at time $t, i j t$, where $i$ denotes a destination country and $j$ stands for a source country. There are seven sources of variation in the data: across destination countries (42.7\% of total variation), across source countries (17\% of total variation), over time ( $0.3 \%$ of total variation) and combinations of the three ( $40 \%$ of total variation). The share of missing observations in the stock variable is $70 \%$ and the share of zeros is $2 \%$.

I begin by describing the key variable $s_{\text {toc }} k_{i j t}$ over two years and across three groups: visa required $(v p=0)$, visa not required for $\mathrm{n}$ days $(v p=1)$, and visa not required $(v p=2)$. Table 3 provides basic descriptive statistics on the pooled sample by visa group. The mean levels of groups are $\bar{x}(v p=0)=14437, \bar{x}(v p=1)=8932$ and $\bar{x}(v p=2)=43265$. The respective median values are $\tilde{x}(v p=0)=80, \tilde{x}(v p=0)=170$, and $\tilde{x}(v p=0)=1679$. Since the ordering of means is not the same as the ordering of medians, the data have a high level of dispersion and the analysis on group means might be misleading.

I split the distribution of stocks in each visa group into ten quantiles and compare the means within each quantile. Table 4 presents the estimates. In quantiles two through nine the mean in the visa partially exempt category is higher than the mean in the visa required category. Only in quantiles one and ten is this trend reversed. This implies that the ranking of group means might be driven by heavy outliers in quantile ten and by zeros in quantile one. High values in quantile ten artificially increase the mean of the

\footnotetext{
${ }^{7}$ According to official language data, Russia-Ukraine, Czech Republic-Slovakia, Turkey-Azerbaijan do not share the same official language, but their residents easily understand each other. In many countries of the former Soviet Union, Russian is the language of everyday communication for many people, even though it is an official language only in the Russian Federation.
} 


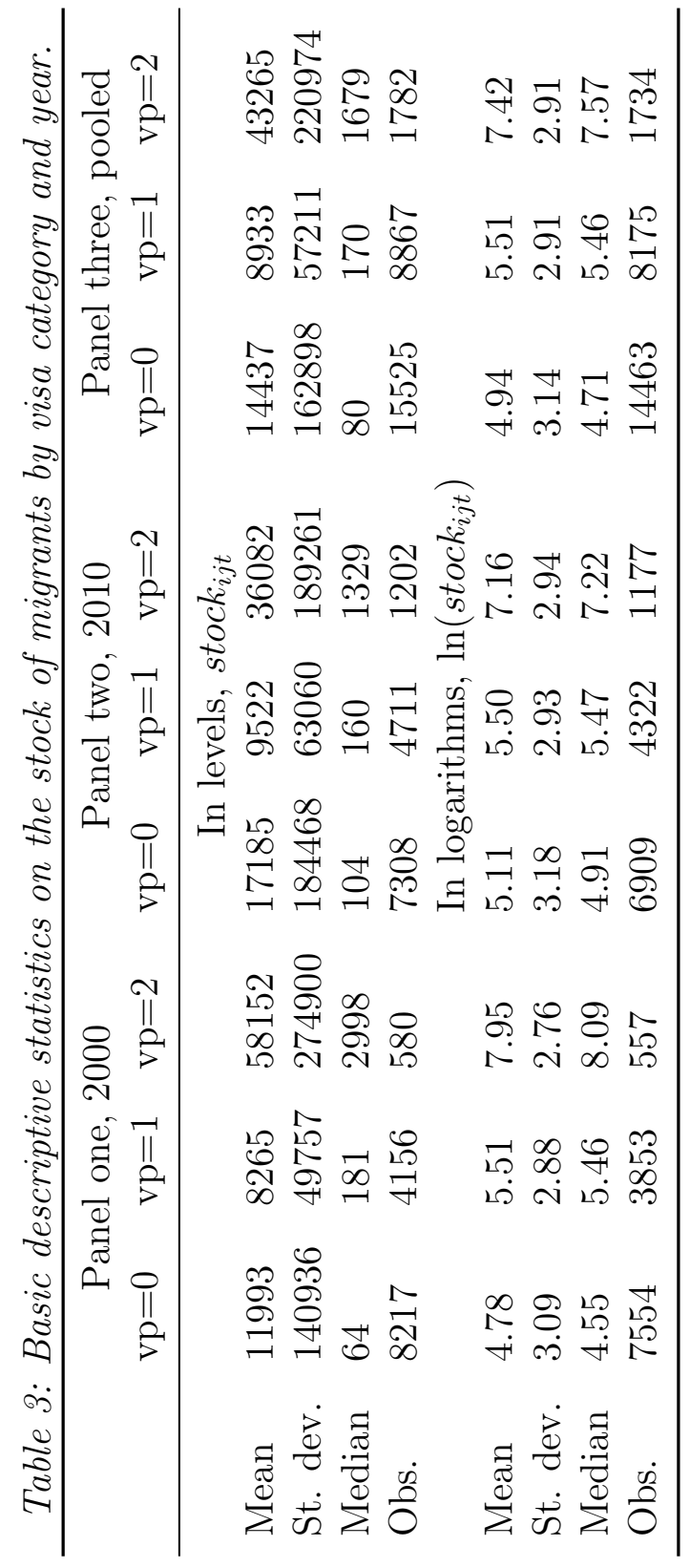

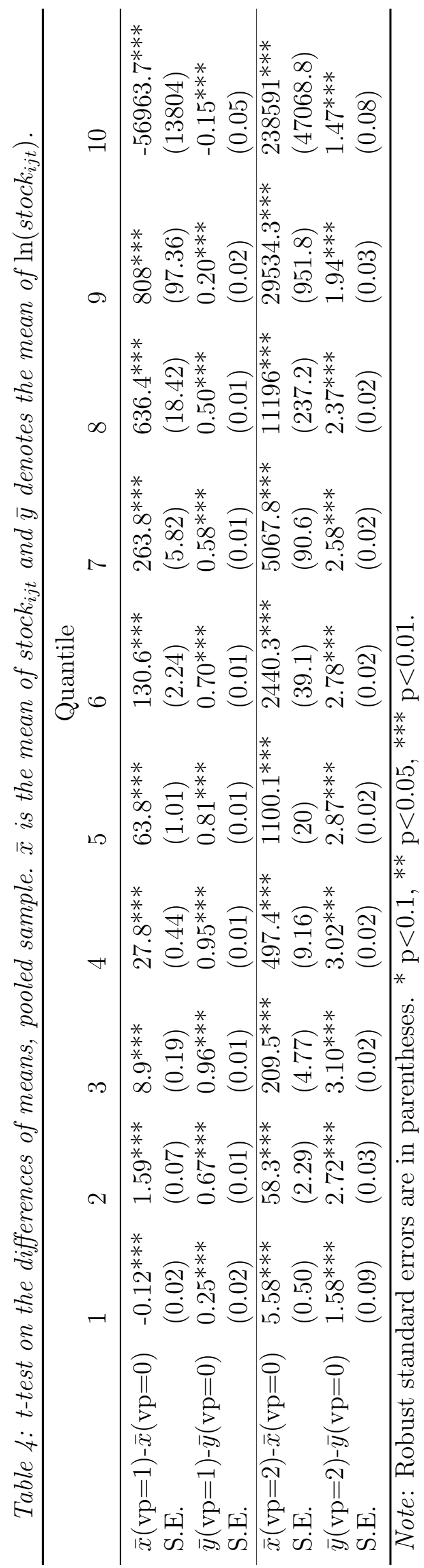


visa required groups and zero values artificially decrease the mean of the visa partially required category. Most prominent examples of country pairs in quantile ten are: migrants in Germany and Israel from the former Soviet Republics, migrants in the United States from Latin America and Chinese migrants in South Korea, Japan and the United States. Typical destination countries with zero values in quantile one are popular tourist destinations, such as: Dominica, Haiti, Ecuador, Maldives, Micronesia and Cook Islands.

To perform formal testing, I apply Kolmogorov-Smirnov and rank-sum nonparametric tests. At 5\% significance level these tests do not reject the hypothesis that the ranking of stocks is $\operatorname{stock}_{i j}(v p=0)<\operatorname{stock}_{i j}(v p=1)<\operatorname{stock}_{i j}(v p=2)$. The logarithmic transformation applied to data reduces dispersion and establishes ranking consistent with the results of the nonparametric tests.

\section{Econometric model and identification}

The baseline specification follows from equations (5) and (9):

$$
y_{i j t}=x_{i j t}^{\prime} \gamma+d_{i}+o_{j}+t_{t}+\epsilon_{i j t} \quad \forall i \neq j,
$$

where $y_{i j t}=\frac{\text { stock }_{i j t}}{\text { pop }_{i t}+\text { pop }_{j t}}, x_{i j t}$ contains country pair specific covariates (without intercept) and $\epsilon_{i j t}$ is a stochastic error which satisfies the Gauss-Markov assumptions. The terms $d_{i}$, $o_{j}$ and $t_{t}$ capture destination, origin country and time unobserved (latent) heterogeneity. Since these terms are not observed, their effects cannot be estimated. Not accounting for their presence in regression leads to omitted variable bias.

To address this problem one should infer the character of the relationship between $d_{i}$, $o_{j}, t_{t}$, and $x_{i j t}$. The simplest and most restrictive relationship is the mean independence assumption $E\left[d_{i} \mid x_{i j t}\right]=d_{i}, E\left[o_{j} \mid x_{i j t}\right]=o_{j}$ and $E\left[t_{t} \mid x_{i j t}\right]=t_{t}$. This assumes that the unobserved heterogeneity is uncorrelated with observed covariates and thus can become part of the error term. Under this assumption regression (11) becomes:

$$
y_{i j t}=\gamma_{0}+x_{i j t}^{\prime} \gamma+\xi_{i j t}
$$

where $\xi_{i j t}$ is a composite error term, $\xi_{i j t}=d_{i}+o_{j}+t_{t}+\epsilon_{i j t}$. Regression (12) is a 
modification of a random effect model and can be consistently estimated by GLS, if its assumptions hold. The Hausman specification test and Wooldridge's test reject the random effect specification in favour of the fixed effect one, implying that the latent heterogeneity is of complex form.

To model the structure of $d_{i}, o_{j}$ and $t_{t}$ I follow three approaches: least squares dummy variable (LSDV), match effects (Mittag, 2012a) and Mundlak's approach (Greene, 2012, Ch. 11; Wooldridge, 2010, Ch. 10). Under the LSDV approach regression (11) becomes:

$$
y_{i j t}=x_{i j t}^{\prime} \gamma_{0}+D_{i}^{\prime} \gamma_{1}+O_{j}^{\prime} \gamma_{2}+T_{t}^{\prime} \gamma_{3}+\nu_{i j t} \quad \forall i \neq j
$$

where $D_{i}$ and $O_{j}$ are column vectors of dummy variables for destination $i$ and origin $j$. $T_{t}$ is a column vector of year dummies. In this equation heterogeneity takes the form of group-specific composite intercept $\left(\gamma_{1}+\gamma_{2}+\gamma_{3}\right)$. Bertoli and Moraga (2013) use origin dummies to control for time invariant characteristics, such as cultural and linguistic proximity.

Under the match effects model individual heterogeneity takes the form of country pair dummy variables. Regression (11) can be re-written as:

$$
y_{i j t}=x_{i j t}^{\prime} \gamma_{0}+D O_{i j}^{\prime} \gamma_{1}+\nu_{i j t} \quad \forall i \neq j
$$

where $D O_{i j}$ is a column vector of country dyad dummy variables. Since adding $i \times j$ dummies increases the dimensionality of the problem, standard matrix inversion techniques are not practical. Mittag (2012a) develops techniques to address this issue.

Under Mundlak's approach, heterogeneity takes the form of destination, origin, and year group means of all regressors:

$$
y_{i j t}=\gamma_{0}+x_{i j t}^{\prime} \gamma_{1}+\bar{x}_{\cdot j t}^{\prime} \gamma_{2}+\bar{x}_{i \cdot t}^{\prime} \gamma_{3}+\bar{x}_{i j}^{\prime} \cdot \gamma_{3}+\mu_{i j t} \quad \forall i \neq j
$$

where $\bar{x}_{\cdot j t}^{\prime}=\frac{1}{N_{i}} \sum_{i=1}^{N_{i}} x_{i j t}^{\prime}, \bar{x}_{i \cdot t}^{\prime}=\frac{1}{N_{j}} \sum_{j=1}^{N_{j}} x_{i j t}^{\prime}$ and $\bar{x}_{i j .}^{\prime}=\frac{1}{2} \sum_{t=\{2000,2010\}} x_{i j t}^{\prime}$.

The preferred specification is regression (15), however equations (13) and (14) are also estimated to check for robustness. Since some countries receive migrants from only a few destinations and some countries send migrants to only a few destinations, the 
intercept is not identified. This leads to the under-identification of the parameters of the visa dummy variables, because they are computed relative to the value of an intercept. This issue persists when the model is checked for robustness using quantile or rolling regressions.

The theoretical model in Section 2 predicts one regression in levels (equation (5)) and the other regression in logarithms (equation (9)). The PE test (Kmenta, 1990, pp. 521-522) rejects the model in levels in favor of the model in logarithms. Intuitively, the specification in logarithms is preferred, because it allows for non-linear relations and smoothes variance thus reducing the amount of outliers and providing a better fit to data (Wooldridge, 2009, p. 328). For the remainder of the paper I will present estimates of the specification in logarithms only.

\section{$7 \quad$ Estimation results}

\subsection{Baseline regression}

The OLS estimates of equations (13) and (15) are reported in Table 5. The exact definitions of variables are given in Table B.2. The key dummy variables of interest, $v p_{1}$ and $v p_{2}$, are positive and significant in all equations. The estimates in specification 1 are biased, because they do not account for group specific heterogeneity. In specification 2 this heterogeneity take the form of destination country, origin country and time dummies.

In specifications 3-5, heterogeneity takes the form of group specific means of variables. Depending on estimated specification, country pairs in groups $v p_{1}$ and $v p_{2}$ account for around 5-15\% more migrants than country pairs with a visa required regime.

Country pairs located further away from each other have fewer migrants. A roughly $1 \%$ increase in distance is associated with an $0.2 \%$ decrease in the stock of migrants. Country pairs that share a similar language account for about $10 \%$ more migration than their counterfactual. Closer cultural and historic links imply slightly more migration. Variables $p c_{2}$ and $p c_{3}$ are positive and significant in specifications 2-5. This suggests that having been part of the same country, having a common colonizer or sharing a common border are significant factors in explaining the stocks of migrants. The sign and 
Table 5: The estimates of equations (13) and (15).

\begin{tabular}{|c|c|c|c|c|c|}
\hline Variable name & $\begin{array}{l}\text { OLS } \\
\text { Spec. } 1\end{array}$ & $\begin{array}{l}\text { OLS } \\
\text { Spec. } 2\end{array}$ & $\begin{array}{l}\text { OLS } \\
\text { Spec. } 3\end{array}$ & $\begin{array}{l}\text { Robust Reg. } \\
\text { Spec. } 4\end{array}$ & $\begin{array}{l}\text { LAD } \\
\text { Spec. } 5\end{array}$ \\
\hline $\mathrm{vp}_{0}$ & \multicolumn{5}{|c|}{ base category } \\
\hline $\mathrm{vp}_{1}$ & $\begin{array}{l}0.161^{* * *} \\
(0.03)\end{array}$ & $\begin{array}{l}0.032^{*} \\
(0.02)\end{array}$ & $\begin{array}{l}0.139^{* * * *} \\
(0.03)\end{array}$ & $\begin{array}{l}0.149^{* * *} \\
(0.02)\end{array}$ & $\begin{array}{l}0.178^{* * *} \\
(0.02)\end{array}$ \\
\hline $\mathrm{vp}_{2}$ & $\begin{array}{l}0.642^{* * *} \\
(0.04)\end{array}$ & $\begin{array}{l}0.056^{*} \\
(0.03)\end{array}$ & $\begin{array}{l}0.155^{* * *} \\
(0.04)\end{array}$ & $\begin{array}{l}0.139^{* * *} \\
(0.04)\end{array}$ & $\begin{array}{l}0.134^{* * *} \\
(0.04)\end{array}$ \\
\hline ln_dist & $\begin{array}{l}-0.374^{* * *} \\
(0.01)\end{array}$ & $\begin{array}{l}-0.217^{* * *} \\
(0.01)\end{array}$ & $\begin{array}{l}-0.190^{* * *} \\
(0.02)\end{array}$ & $\begin{array}{l}-0.132^{* * *} \\
(0.01)\end{array}$ & $\begin{array}{l}-0.112^{* * *} \\
(0.01)\end{array}$ \\
\hline ln_wgap & $\begin{array}{l}0.703^{* * *} \\
(0.06)\end{array}$ & $\begin{array}{l}0.509^{* * *} \\
(0.18)\end{array}$ & $\begin{array}{l}-0.058 \\
(0.07)\end{array}$ & $\begin{array}{l}0.044 \\
(0.06)\end{array}$ & $\begin{array}{l}-0.030 \\
(0.05)\end{array}$ \\
\hline ln_stock_prev & $\begin{array}{l}0.700^{* * * *} \\
(0.00)\end{array}$ & $\begin{array}{l}0.876^{* * * *} \\
(0.01)\end{array}$ & $\begin{array}{l}0.908^{* * * *} \\
(0.01)\end{array}$ & $\begin{array}{l}0.942^{* * *} \\
(0.01)\end{array}$ & $\begin{array}{l}0.950^{* * * *} \\
(0.00)\end{array}$ \\
\hline lang & $\begin{array}{l}0.255^{* * * *} \\
(0.03)\end{array}$ & $\begin{array}{l}0.164^{* * *} \\
(0.02)\end{array}$ & $\begin{array}{l}0.123^{* * *} \\
(0.03)\end{array}$ & $\begin{array}{l}0.081^{* * *} \\
(0.03)\end{array}$ & $\begin{array}{l}0.063^{* *} \\
(0.03)\end{array}$ \\
\hline $\mathrm{pc}_{1}$ & $\begin{array}{l}0.044^{* * * *} \\
(0.01)\end{array}$ & $\begin{array}{l}0.017^{* * * *} \\
(0.01)\end{array}$ & $\begin{array}{l}0.004 \\
(0.01)\end{array}$ & $\begin{array}{l}-0.009 \\
(0.01)\end{array}$ & $\begin{array}{l}-0.003 \\
(0.01)\end{array}$ \\
\hline $\mathrm{pc}_{2}$ & $\begin{array}{l}0.003 \\
(0.01)\end{array}$ & $\begin{array}{l}0.055^{* * *} \\
(0.01)\end{array}$ & $\begin{array}{l}0.042^{* * *} \\
(0.01)\end{array}$ & $\begin{array}{l}0.047^{* * *} \\
(0.01)\end{array}$ & $\begin{array}{l}0.057^{* * *} \\
(0.01)\end{array}$ \\
\hline $\mathrm{pc}_{3}$ & $\begin{array}{l}-0.182^{* * *} \\
(0.01)\end{array}$ & $\begin{array}{l}0.068^{* * * *} \\
(0.01)\end{array}$ & $\begin{array}{l}0.073^{* * * *} \\
(0.01)\end{array}$ & $\begin{array}{l}0.069^{* * * *} \\
(0.01)\end{array}$ & $\begin{array}{l}0.073^{* * * *} \\
(0.01)\end{array}$ \\
\hline cons & $\begin{array}{l}-1.959^{* * *} \\
(0.13)\end{array}$ & $\begin{array}{l}-2.727^{* * *} \\
(0.23)\end{array}$ & $\begin{array}{l}-2.627^{* *} \\
(1.08)\end{array}$ & $\begin{array}{l}0.581 \\
(0.96)\end{array}$ & $\begin{array}{l}-1.650^{* * *} \\
(0.32)\end{array}$ \\
\hline Adj. $R^{2}$ & 0.733 & 0.925 & 0.817 & 0.860 & 0.813 \\
\hline
\end{tabular}

Notes: The dependent variable is $\ln \left(\right.$ stock $\left._{i j t}\right)$. The number of observations is 18661 in each equation. Spec. 1 does not account for heterogeneity. Spec. 2 includes destination, origin, and year dummies. Spec. 3-5 contain the group means of the variables. In spec. $5 R^{2}$ is computed as the square of the correlation coefficient. Robust standard errors are in parentheses. ${ }^{*} \mathrm{p}<0.1,{ }^{* *} \mathrm{p}<0.05,{ }^{* * *} \mathrm{p}<0.01$. 
significance on ln_stock_prev variable means strong persistence: destinations with a high diaspora of a certain nationality in the past, will continue to have high stocks of this nationality in the future. These estimates are in line with the findings of other studies mentioned in Table B.1.

The sign and significance on the income gap variable, $l n \_w g a p$, is inconclusive at this stage. Mayda (2010) mentions that the sign might not agree with theoretical predictions, because GDP per capita is a measure of average wages and thus ignores variation across skill levels. A worker might get a higher return on skills in a less developed country or move there to start a business. Also, Pedersen et al. (2008) suggest that the effect of income on migration is non-linear. This is addressed in subsection 7.2.

Further, I look at whether the policy index can explain variation in the male-female migration gap. The average share of females in the sample is 0.47 with a standard error of 0.001 . The hypothesis that the female share in migrant population equals 0.5 is clearly rejected. I regress the share of females on the set of covariates and present the results in Table B.6. All four specifications indicate that the share of female migrants in the visa not required group is slightly, but significantly, lower than in the other two groups. The difference is almost 10 more females per 1000 of migrants at destination, or approximately $2 \%$ (specification 3 ).

Using the data from Brücker et al. (2013), I compute the share of skilled migrants for each country pair and regress it on the baseline set of covariates. The OLS and alternative estimates of this regression are presented in Table B.7. The OLS estimates (specifications 1 and 3) show that the share of skilled migrants does not differ across pairs assigned to different visa categories. However, the estimates from robust regression suggest a negative relationship between these variables. Based on this I conclude that the share of skilled migrants is not larger for country pairs with simplified visa requirements.

\subsection{Nonlinear effects}

The assignment of country pairs into $v p_{0}, v p_{1}$, and $v p_{2}$ groups largely depends on the magnitude of the income gap. Most destinations give visa waivers to origin countries of about the same level of economic development or above. It is difficult to find many instances 
when an underdeveloped country has a visa free entry to a developed destination.

The estimate on income gap in the previous section is insignificant in several specifications because, as existing studies suggest, the relationship between income and migration stock is nonlinear. For example, Pedersen et al. (2008) find an inverse U-shaped effect of income at origin on migration. I investigate nonlinearities by income gap quantile and entry visa category. I conjecture that as entry restrictions are lifted, migrants become more responsive to the income gap. In the visa not required category the sign at $l n \_w g a p$ should not contradict theoretical predictions from Section 2 .

I split the distribution of the income gap into 12 quantiles and estimate equation (15) within each quantile and visa category. The confidence intervals of the estimates by quantile are shown in Figure 2 and the estimates by visa group are illustrated in Table B.5. Figure 2(a) shows that the wage gap variable does not explain any variation in migrant stock for country pairs in the visa required group. I explain this by the fact that workers do not react to the wage gap due to institutional factors: it is very difficult and costly to obtain an employment visa. When this institutional barrier is partially reduced in Figure 2(b), the income gap affects migration stock positively for country pairs that are not too far off from each other in terms of average income.

Finally, when visa barriers are entirely removed in Figure 2(c), the effect of the wage gap is positive for most of the income gap distribution. For high values of the wage gap the effect reduces to zero for two reasons. First, it is difficult to finance the move when a person comes from a low-income country. The negative effect of poverty on migration is also found in the studies of Mayda (2010) and Pedersen et al. (2008). Second, there is an attrition problem in the data: as the wage gap increases, the visa not required group becomes too small and the effect is not identified.

The estimated nonlinear effects are in line with the intuition and findings of other authors. Belot and Ederveen (2012) run a separate regression for country pairs with unrestricted labor mobility. They find that the effects of network, physical distance, cultural and linguistic distance factors weaken or even disappear for this subgroup. The estimation by quantiles is methodologically similar to the study of Beine et al. (2011), who run a rolling regression to estimate the non-linear effects of diaspora size. 


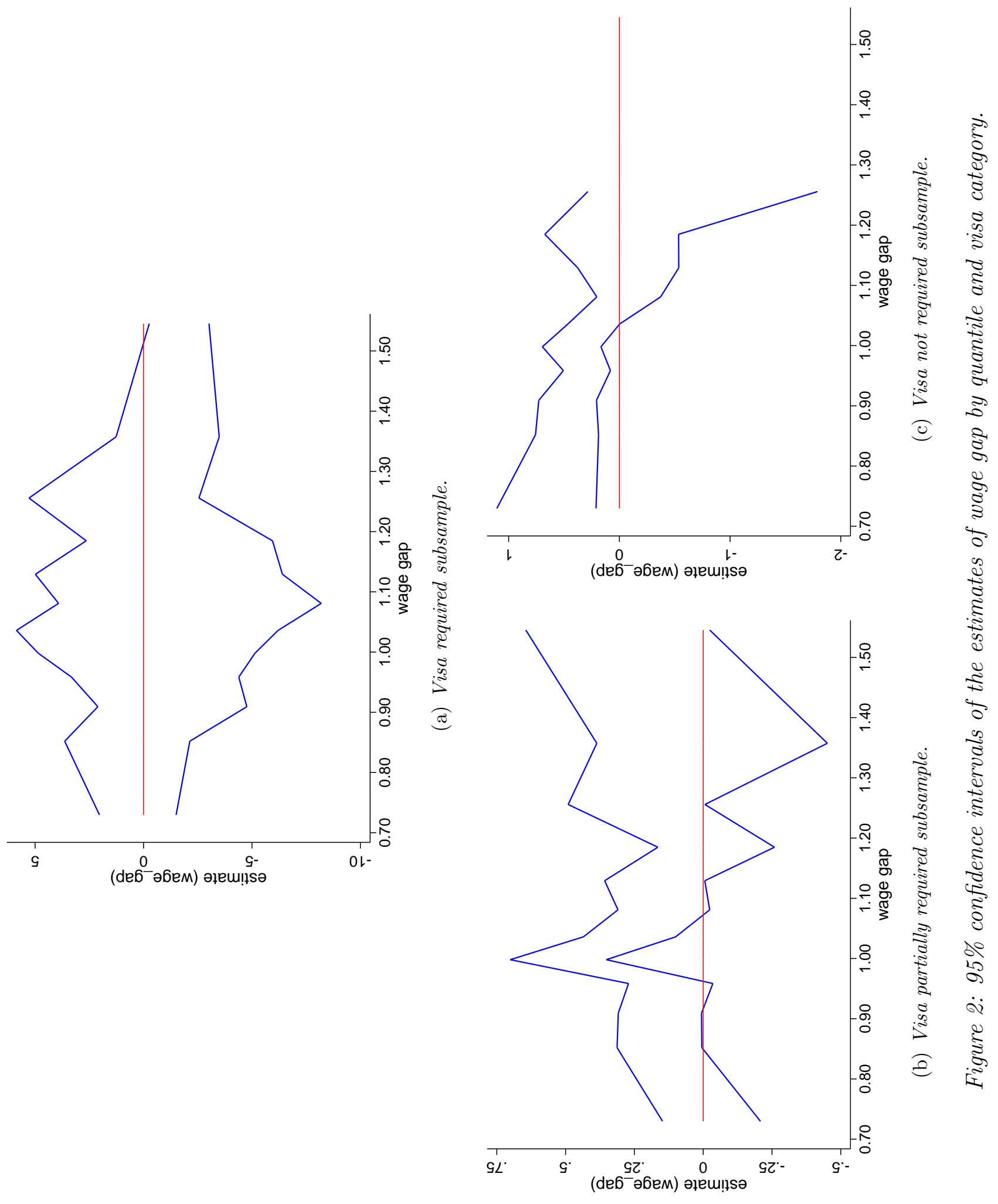




\subsection{Difference-in-difference estimates}

In this section I discuss the effects of policy changes on the stock of migrants, the share of females and share of skilled migrants. The estimates in levels discussed until now might suffer from one drawback. Even though I account for destination country, origin country, and year effects, the visa variables might capture the effects of unobservable characteristics. By construction, the difference-in-difference estimation reduces this kind of bias.

As discussed in Section 4, up-shifter country pairs can be of three types: visa required changes to visa partially required $\left(v p_{0}\right.$ to $\left.v p_{1}\right)$, visa required changes to visa not required $\left(v p_{0}\right.$ to $\left.v p_{2}\right)$ and visa partially required changes to visa not required $\left(v p_{1}\right.$ to $\left.v p_{2}\right)$. Symmetrically, down-shifter dyads are: visa partially required changes to visa required ( $v p_{1}$ to $\left.v p_{0}\right)$, visa not required changes to visa required $\left(v p_{2}\right.$ to $\left.v p 0\right)$ and visa not required changes to visa partially required $\left(v p_{2}\right.$ to $\left.v p_{1}\right)$.

I pool up-shifter pairs in one group and down-shifter pairs in the other group and estimate the effects of policy weakening and tightening. The OLS estimates of the key parameters of interest are illustrated in Table 6. They suggest that before the policy change the up-shifter and down-shifter pairs are not statistically different from nonshifter pairs in terms of migrant stocks and the shares of females and skilled migrants. Controlling for all other covariates, the levels of stocks and the shares of skilled migrants in 2010 are not statistically different from their values in 2000. This, however, is not true for the share of females, which declined in 2010. After the policy change, the up-shifter pairs account for $10 \%$ more migrants than their non-shifter counterparts. This is equivalent to 7 more people per $10 \mathrm{mln}$. of the destination plus origin population. Up-shifter pairs have also smaller shares of females and skilled migrants, both in the magnitude of about 14 migrants per 1000 of migrant stocks at destination. This is equivalent to a $3 \%$ decline in the share of females and $3.5 \%$ in the share of skilled migrants.

The effect on down-shifters is not symmetric. The estimates of the baseline specification indicate that the introduction of visas is not associated with any significant change in the stocks of migrants, the shares of females and skilled migrants. In Table B.8, I provide alternative estimates from robust regression, which suggest even a stronger result: 


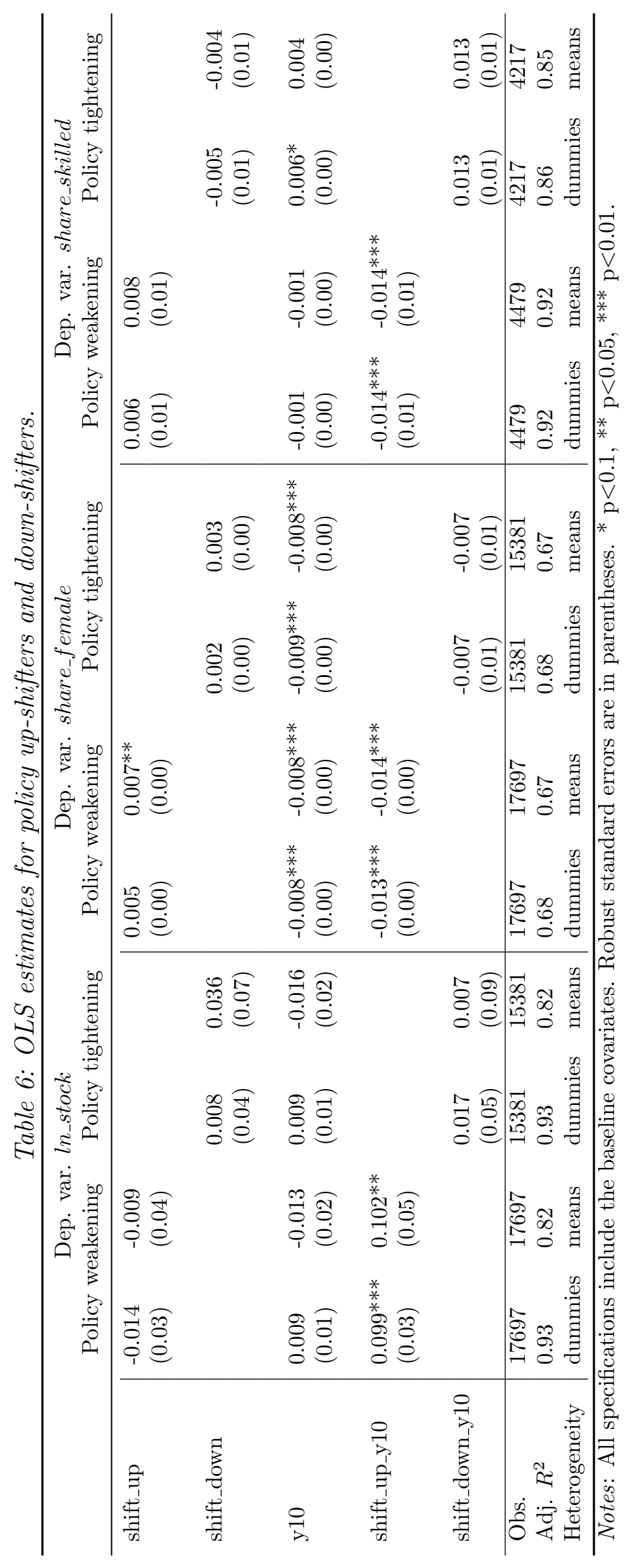


the tightening of immigration policy is associated with an increase in the share of skilled migrants.

Two major effects generate this asymmetric result: the abolition (introduction) of visas and migrant networks. When immigration policy is weakened, institutional barriers to migration are removed and migrants' costs are reduced. Symmetrically, the tightening of the immigration policy imposes additional institutional constraints thus increasing costs. The effect of networks always works in one direction. More migrants of the same nationality or speaking the same language at destination translates into smaller migration and integration costs, as well as the costs of social exclusion. Numerous studies based on micro and macro data document that migrant communities at the destination support one another in various ways (Munshi, 2003).

When the visa policy weakens, both effects reduce migration costs. However, when visas are imposed, the two effects work in opposite directions. Visas increase costs, but high migrant stocks decrease costs. Shortly after the introduction of visas, the network effect dominates and the stock of migrants does not decrease immediately. With the passing of time, the institutional factor might offset the network effect and the pool of migrants might reduce.

In Figure C.1, I plot OLS estimates and associated 95\% confidence intervals of the effects of policy changes by the type of change. Figures 1(a) and 1(c) show that the effects of policy weakening on the stocks and the share of skilled migrants are driven by the shifts to the visa not required category ( $v p_{0}$ to $v p_{2}$ and $v p_{1}$ to $v p_{2}$ in the figures). The effect on the share of females is to a large extent generated by the visa partially required to visa not required shift ( $v p_{1}$ to $v p_{2}$ in the figure).

The effects on down-shifter pairs is not statistically significant for all types of policy tightening changes. In the bottom graph, the effects on $v_{2}$ to $v p_{0}$ and $v p_{2}$ to $v p_{1}$ cannot be identified, because the data for these country pairs are not available.

\subsection{Robustness check}

I check the robustness of the results using alternative estimators and estimating the placebo effect. Besides OLS estimates with robust standard errors, in most tables I 
include alternative results from robust regression or LAD estimates (Verardi and Croux, 2009). If OLS assumptions are not violated, then OLS estimates are preferred. If these assumptions are violated, then alternative estimates should be considered, because they are robust to model misspecifications. To this end, I only present results which are confirmed by OLS and alternative estimates.

I further estimate regression (14) with match effects (destination-origin dummies). ${ }^{8}$ The advantage of this approach is that it accounts for destination-origin heterogeneity. Since the number of estimated parameters increases, the usual matrix inversion technique is not practical and Mittag (2012a) suggests using a conjugate gradient method. The effects identified on time variant variables suggest a similar picture to the one discussed in sub-section 7.1.

In Figure C.2, I plot the estimates of the placebo effect obtained from three simulations, 500 iterations each. Within each iteration, I randomly choose a group of country pairs from visa required category and run DiD estimation. Since the visa regime did not change between these country pairs, there should be no statistically significant effect on stocks, their gender and education composition. The DiD estimates in Figure C.2 confirm this conjecture. The confidence intervals in Figure 2(a) are relatively wide and contain zero at each iteration. Each of the Figures 2(b) and 2(c) contains about 20 iterations that do not cross the zero line, implying that the placebo effect exists. This, however, is consistent with the definition of a $95 \%$ confidence interval: in $5 \%$ of cases the estimated interval will not include the value of a true population parameter (type I error). This allows for each simulation to have at most 25 such misclassified iterations.

\subsection{Discussion of endogeneity}

There are two potential sources of endogeneity here: omitted variable bias and reverse causality. The assignment of country pairs to visa categories is determined by a multiplicity of factors and some of them are not included in the estimation because they are unobserved or unavailable. The created variables $v p_{0}, v p_{1}$, and $v p_{2}$ might thus correlate with the error term. To address this problem, each equation is estimated with group

\footnotetext{
${ }^{8}$ For the estimation I use twfe STATA module developed by Mittag (2012b).
} 
specific means of covariates, origin and destination dummies or country pair dummies. These variables sufficiently account for any unobserved country specific characteristics.

Reverse causality might affect the results because countries with higher stocks of migrants might have stricter immigration policies. The stock of migrants and immigration policy might affect each other. To account for this I include lagged stocks of migrants into each regression. For 2010 and 2000 the lagged values are the levels in 2005 and 1995 respectively. Since the estimation is performed for 2010 and 2000 only, the inclusion of the lagged values does not cause the Arellano-Bond type correlation, because the equations are not estimated for 2005 and 1995 due to data unavailability.

I include a short discussion on three potential instruments for the visa variables: crime rates, visa rejection rates and membership in unions. These instruments are motivated with examples below. However I am not convinced that any of them satisfies the requirements of a valid instrument.

In 2009, the UK imposed visas on the citizens of South Africa after numerous cases of South African passports being stolen and later misused by other nationalities to get into the UK illegally. Data on crime rates could be a proxy for the frequency of passport steals. However, data show that per capita crime rates in developing countries are smaller that in developed countries, thus invalidating this instrument due to a measurement error.

The visa rejection rate is a proxy for the laxity of visa rules. If the rejection rate is low, then potential migrants do not need enhanced screening and visa rules could be loosened or entirely abolished. A low rejection rate on B-type visas is one of key criterion to join the US Visa Waiver Program. These data are available only for the US.

Membership in international organizations or unions can tell something about the credibility of a country in question. After joining the EU, some of the new member states were also added to visa waiver programs in the US, New Zealand, and South Korea. This can be a regional instrument for the EU origin countries, however this information cannot be extended to other continents, where the analogy of the EU does not exist. 


\subsection{Discussion of results}

The abolition of visas reduces institutional barriers to mobility. This pushes more people to migrate in response to cross country income gaps. The increase in migrant stocks from policy affected countries for the period 2000-2010 was around 10\%. The growth was mostly in male and unskilled migration. This effect is robust to alternative estimation techniques and specifications.

The selection on gender has to do with the traditional breadwinning role of males in households in many developing economies. Low labor market participation rates for females (World Bank, 2014) combined with low emigration rates (Commander et al., 2013) translate to a gender gap in the migrant stock data. This gap is further widened for country pairs with lax visa rules.

The skill bias is generated by the fact that skilled migrants are less affected by visa restrictions in general. Since many developed destinations have adopted skill-biased immigration policies, it is easier for skilled migrants to obtain a visa. Such migrants are less bound by visa constraints and choose to migrate to destinations that value their skills most.

In contrast, the introduction of visas is not associated with a statistically significant reduction in migrant stocks or their gender or skill composition. Such an asymmetric picture suggests the existence of "immigration policy hysteresis:" it is easy to use immigration policy to increase the stock of migrants, but it is ineffective in reducing migrant stocks in the short run. ${ }^{9}$

Visa restrictions turn out ineffective in the short run for several reasons. First, the introduction of visas affects potential migrants more (migrants in flow data) than current migrants at destination (migrants in stock data). Time is needed for changes in flow data to translate to changes in stocks data. Second, as the estimates in Table 5 illustrate, the magnitude of the network effect exceeds the effect of visas by a factor of six. The immigration policy effect is not strong enough to offset the network effect which even strengthens after the introduction of visas (see Table B.5). It is interesting to further research if and when the visa effect overtakes the network effect. Unfortunately, the data

\footnotetext{
${ }^{9}$ An excellent overview the usage of concept "hysteresis" in Economics is provided by Göcke (2002).
} 
at hand do not allow this question to be addressed. Third, firms always demand cheap labor and might lobby for more temporary migrant workers irrespective of visa regime.

\section{Conclusion}

In this paper I achieve two objectives. First, I construct an immigration policy index that varies across sending and receiving countries as well as over time. The index has an intuitive design and clear interpretation in estimation. Second, I use the constructed index to estimate the effects of the introduction and abolition of visas on the stocks of migrants, their gender and education composition.

I find that country pairs with visa partially required and visa not required regimes account for $13 \%$ and $15 \%$ more migrants respectively than pairs with visa required status. The effect of other determinants also varies by visa category. The effects of wage gap, language and cultural proximity are the strongest in the visa not required category. The effects of distance and diaspora are the strongest in the visa required category.

This result is quite intuitive. If entry visas are required, then migrants move to destinations with large numbers of migrants of their nationality and which are close geographically. If entry visas are absent, then migrants are less restricted in their choice of destination. They usually go to more developed countries and destinations similar in language and culture.

The difference-in-difference estimates show that the introduction of visas is associated with an increase in migrant stocks and a change in gender and skill composition towards more male and less skilled. In contrast, the introduction of visas does not affect the stocks of migrants, their gender or education composition for the period considered. This asymmetric picture hints at the existence of hysteresis effect in how migrant stocks respond to changes in immigration policies. 


\section{References}

Alesina, A., Devleeschauwer, A., Easterly, W., Kurlat, S., Wacziarg, R., 2003. Fractionalization. Journal of Economic Growth 8 (2), 155-194.

Artuc, E., Docquier, F., Özden, Ç., Parsons, C., 2013. A global assessment of human capital mobility: the role of non-OECD destinations.

Barro, R. J., Lee, J. W., 2013. A new data set of educational attainment in the world, 1950-2010. Journal of Development Economics 104 (0), 184-198.

Beine, M., Docquier, F., Özden, Ç., 2011. Diasporas. Journal of Development Economics $95(1), 30-41$.

Belot, M., Ederveen, S., 2012. Cultural barriers in migration between OECD countries. Journal of Population Economics 25 (3), 1077-1105.

Bertoli, S., Moraga, J. F.-H., 2013. Multilateral resistance to migration. Journal of Development Economics 102 (0), 79-100.

Brücker, H., Capuano, S., Marfouk, A., 2013. Education, gender and international migration: insights from a panel dataset 1980-2010. mimeo.

Commander, S., Nikolaychuk, O., Vikhrov, D., 2013. Migration from Ukraine: brawn or brain? New survey svidence. IZA Discussion Papers 7348.

Defoort, C., 2008. Long-term trends in international migration: an analysis of the six main receiving countries. Population-E 63 (2), 285-318.

Docquier, F., Rapoport, H., Salomone, S., 2012. Remittances, migrants' education and immigration policy: theory and evidence from bilateral data. Regional Science and Urban Economics 42 (5), 817-828.

Feenstra, R. C., Inklaar, R., M.P., T., 2013. The next generation of the Penn World Table. Available for download at www.ggdc.net/pwt.

Freeman, R. B., Oostendorp, R., 2000. Wages around the world: pay across occupations and countries. Working Paper 8058, National Bureau of Economic Research.

Glaesser, D., Kesler, J., 2013. Tourism visa openness report. Tech. rep., World Tourism Organization, Madrid.

Glick, R., Rose, A. K., 2002. Does a currency union affect trade? The time-series evidence. European Economic Review 46 (7), 1125-1151.

Göcke, M., 2002. Various concepts of hysteresis applied in Economics. Journal of Economic Surveys 16 (2), 167-188.

González, X., Miles-Touya, D., 2014. Admission policies and immigrant skills. Applied Economics Letters 21 (17), 1189-1193.

Greene, W. H., 2012. Econometric analysis, 7th Edition. Prentice hall. 
Grogger, J., Hanson, G. H., 2011. Income maximization and the selection and sorting of international migrants. Journal of Development Economics 95 (1), 42-57.

Head, K., Mayer, T., 2015. Chapter 3 - Gravity equations: workhorse, toolkit, and cookbook. In: Elhanan Helpman, K. R., Gopinath, G. (Eds.), Handbook of International Economics. Vol. 4. Elsevier Science, pp. 131-195.

Head, K., Mayer, T., Ries, J., 2010. The erosion of colonial trade linkages after independence. Journal of International Economics 81 (1), 1-14.

Hobolth, M., 2014. Researching mobility barriers: The European visa database. Journal of Ethnic and Migration Studies 40 (3), 424-435.

Hofstede, G., Hofstede, G., Minkov, M., 2010. Cultures and organizations: software of the mind, 3rd Edition. McGraw-Hill Education.

Huddleston, T., Niessen, J., Chaoimh, E. N., White, E., 2011. Migrant integration policy index. Tech. rep., British Council and Migration Policy Group, Brussels.

IATA, 1998. Travel information manual (3).

IATA, 2009. Travel information manual (11).

Inglehart, R., Baker, W. E., 2000. Modernization, cultural change, and the persistence of traditional values. American Sociological Review 65 (1), 19-51.

Kahanec, M., Pytlikova, M., Zimmermann, K. F., 2014. The free movement of workers in an enlarged european union: institutional underpinnings of economic adjustment. IZA Discussion Papers 8456.

Kmenta, J., 1990. Elements of Econometrics, 2nd Edition. Macmillan Publishing.

Lewis, M. P., Simon, G. F., Fennig, C. D., 2013. Ethnologue: languages of the world, 17th Edition. SIL International, Dallas, Texas.

Mayda, A. M., 2010. International migration: a panel data analysis of the determinants of bilateral flows. Journal of Population Economics 23 (4), 1249-1274.

Mayer, T., Zignago, S., 2011. Notes on CEPII's distance measures: the GeoDist database. Working Papers 2011-25, CEPII.

Melitz, J., Toubal, F., 2014. Native language, spoken language, translation and trade. Journal of International Economics 93 (2), 351-363.

Mittag, N., 2012a. New methods to estimate models with large sets of fixed effects with an application to matched employer-employee data from Germany. FDZ-Methodenreport $2012(2)$.

Mittag, N., 2012b. TWFE: Stata module to perform regressions with two-way fixed effects or match effects for large datasets. Statistical Software Components, Boston College, Department of Economics. 
Munshi, K., 2003. Networks in the modern economy: Mexican migrants in the US labor market. The Quarterly Journal of Economics 118 (2), 549-599.

Neumayer, E., 2010. Visa restrictions and bilateral travel. The Professional Geographer $62(2), 171-181$.

OECD, 2013. International migration outlook 2013. OECD Publishing.

Ortega, F., Peri, G., 2013. The effect of income and immigration policies on international migration. Migration Studies 1 (1), 47-74.

Özden, Ç., Parsons, C., Schiff, M., Walmsley, T., 2011. Where on earth is everybody? World Bank Economic Review 25 (1), 12-56.

Palmer, J., Pytlikova, M., 2013. Labor market laws and intra-European migration: The role of the state in shaping destination choices. CReAM Discussion Paper Series 1311.

Pedersen, P., Pytlikova, M., Smith, N., 2008. Selection and network effects - migration flows into OECD countries 1990-2000. European Economic Review 52 (7), 1160-1186.

Rosenzweig, M., 2010. Global wage inequality and the international flow of migrants. Discussion paper 983, Economic Growth Center, Yale University.

Solt, F., 2014. The standardized world income inequality database, working paper. SWIID Version 5.0, October 2014.

UN, 2011. International migrant stock by origin: the 2010 revision. Population Division, Migration Section.

UN, 2013. Trends in international migrant stock: Migrants by destination and origin.

Verardi, V., Croux, C., 2009. Robust regression in Stata. Stata Journal 9 (3), 439-453.

Vyas, S., Kumaranayake, L., 2006. Constructing socio-economic status indices: how to use principal components analysis. Health Policy and Planning 21 (6), 459-468.

Wooldridge, J. M., 2009. Introductory econometrics: a modern approach, 4th Edition. South-Western Cengage Learning.

Wooldridge, J. M., 2010. Econometrics of cross-section and panel data, 2nd Edition. MIT Press.

World Bank, 2014. World development indicators 2014. Report, World Bank. 


\section{A Derivation of Gini index}

The model economy consists of two skill types. Since this is a generalization of real world with a continuum of skill types, sectoral wages $w_{L}$ and $w_{H}$ are not readily available in data. These wages can be derived from an average wage and the Gini index.

An average wage in the model is:

$$
W=\alpha \cdot w_{H}+(1-\alpha) \cdot w_{L}
$$

In Figure A.1, I plot the shares of workers against their cumulative wealth.

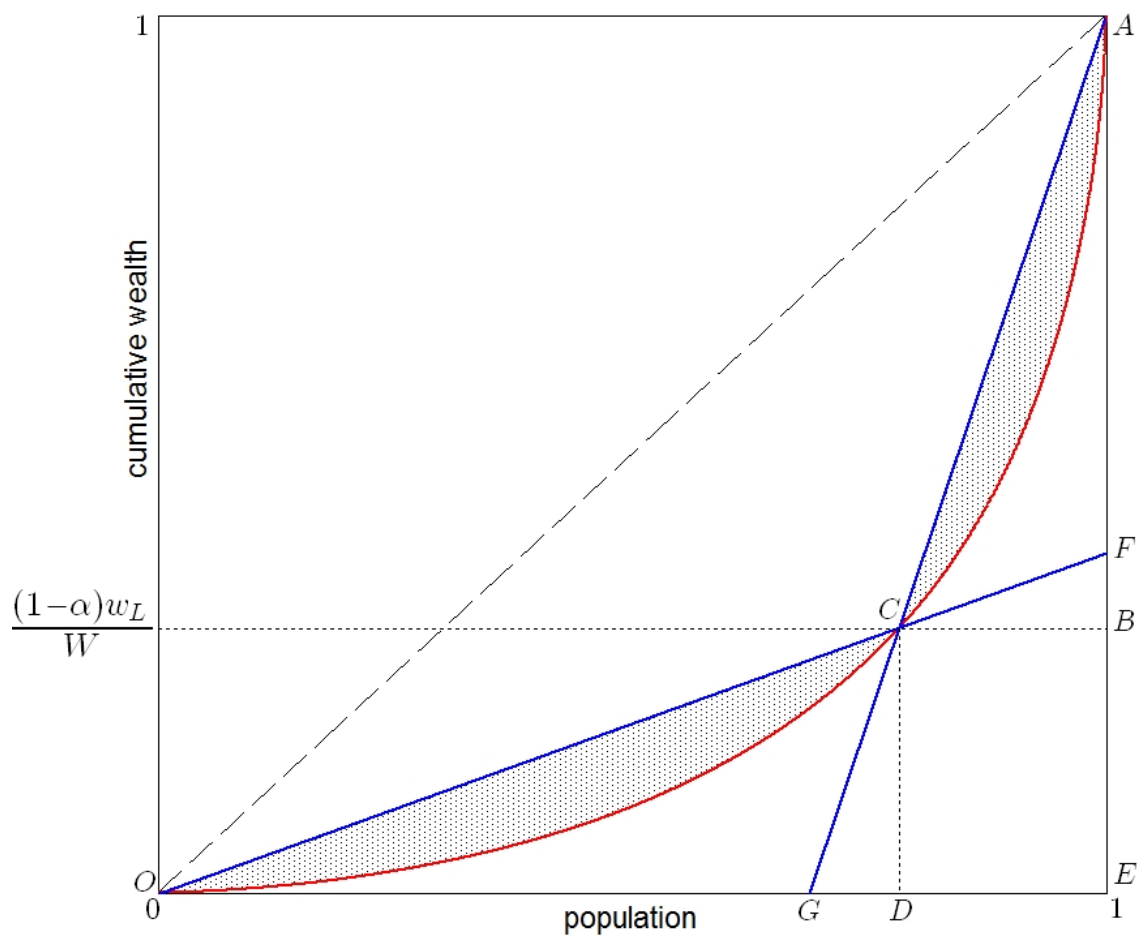

Figure A.1: The Gini index for the model.

Unskilled workers contribute $\frac{(1-\alpha) w_{L}}{W}$ share to total wealth, and skilled workers contribute $\frac{\alpha w_{H}}{W}$. The slope of the unskilled line $O F$ is $\frac{w_{L}}{W}$ and the slope of the skilled line is $\frac{w_{H}}{W}$. The Gini index is the ratio of the area of triangular $O C A, S_{O C A}$, to the area of triangular $O E A, S_{O E A}$ :

$$
G=\frac{S_{O C A}}{S_{O E A}}=2 \cdot S_{O C A}=\frac{\alpha(1-\alpha)\left(w_{H}-w_{L}\right)}{(1-\alpha) w_{L}+\alpha w_{H}}
$$


where:

$$
\begin{aligned}
& S_{O C A}=\frac{1}{2}-S_{O D C}-S_{D C B E}-S_{C B A} ; \quad S_{O D C}=\frac{1}{2} \frac{(1-\alpha)^{2} w_{L}}{(1-\alpha) w_{L}+\alpha w_{H}}, \\
& S_{D C B E}=\frac{\alpha(1-\alpha) w_{L}}{(1-\alpha) w_{L}+\alpha w_{H}} ; \quad S_{C B A}=\frac{1}{2} \frac{\alpha^{2} w_{H}}{(1-\alpha) w_{L}+\alpha w_{H}} .
\end{aligned}
$$

Using equations (16) and (17) the sectoral wages are:

$$
\begin{aligned}
& w_{H}=W\left(1+\frac{G}{\alpha}\right), \\
& w_{L}=W\left(1-\frac{G}{1-\alpha}\right) .
\end{aligned}
$$

Equations (18) and (19) are easy to interpret. If both skill types earned the same wage, it would be equal to the average wage and the Gini index would be zero. Since $w_{H}>w_{L}$, the skilled wage is $W\left(\frac{G}{\alpha}\right)$ above the average wage and the unskilled wage is $W\left(\frac{G}{1-\alpha}\right)$ below the average wage.

When compared to the real world with a multiplicity of skill types, the Gini index in equation (17) underestimates the degree of inequality. The degree of underestimation equals the shaded area in Figure A.1. There are two ways to account for this. One could compute the degree of underestimation (shaded areas) and adjust the Gini index of the model accordingly. Alternatively, one could redefine what a "skilled" worker is, thus adjusting $\alpha$. I follow the latter approach: an unskilled worker is defined as having zero years of education and a skilled worker has 26 years of education. 
B Tables 


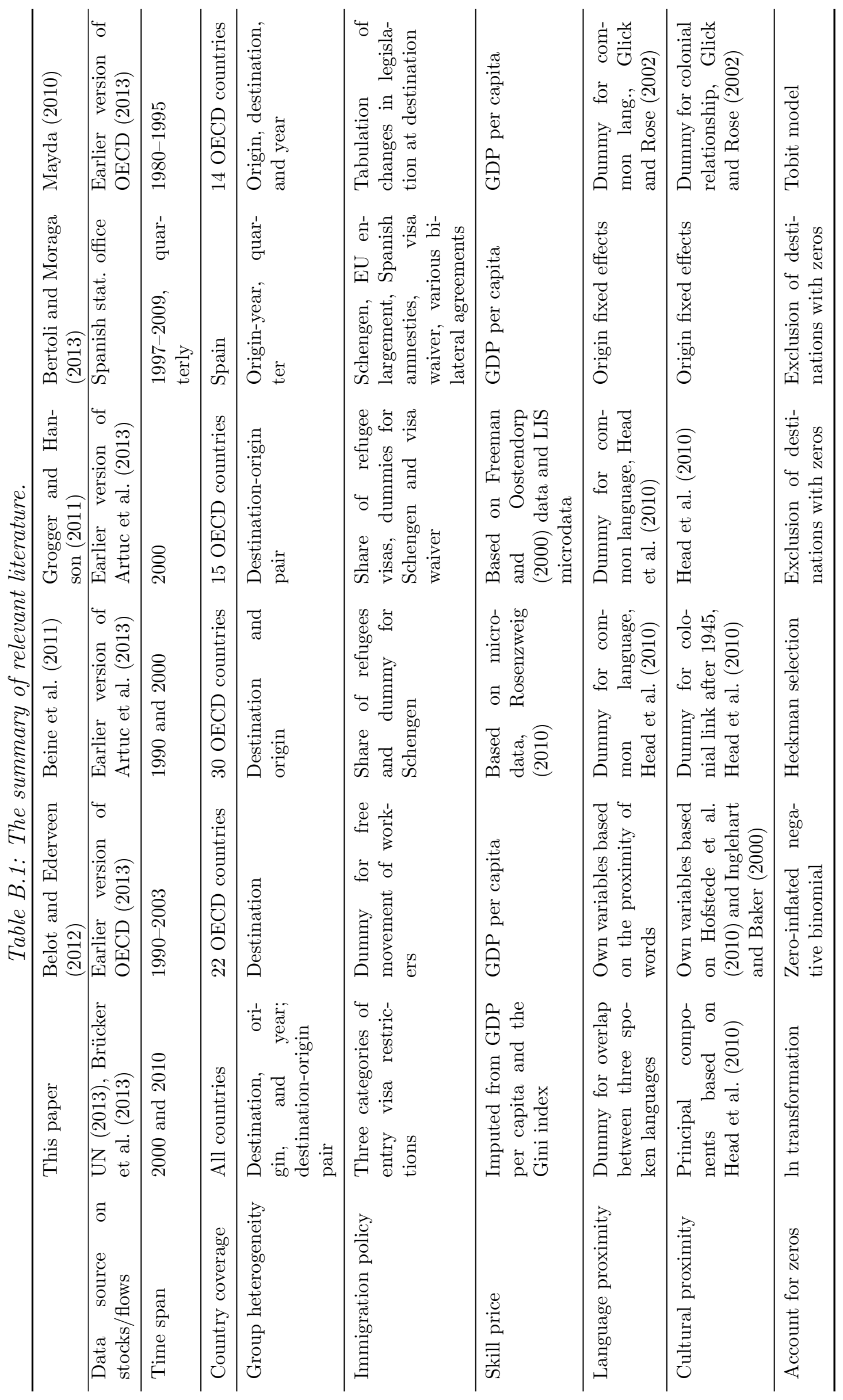


Table B.2: Definitions of covariates and data sources.

\begin{tabular}{|c|c|c|}
\hline Var. name & Definition & Primary source \\
\hline $\mathrm{vp}_{0}, \mathrm{vp}_{1}, \mathrm{vp}_{2}$ & $\begin{array}{l}\text { Dummy variables for visa required, visa par- } \\
\text { tially required and visa not required, respec- } \\
\text { tively. }\end{array}$ & $\begin{array}{l}\text { Own computation us- } \\
\text { ing IATA (1998) and } \\
\text { IATA (2009) data. }\end{array}$ \\
\hline $\begin{array}{l}\text { shift_up, } \\
\text { shift_down }\end{array}$ & $\begin{array}{l}\text { Dummy variables for country pairs which } \\
\text { weakened and tightened their immigration } \\
\text { policies, respectively. }\end{array}$ & Own computation \\
\hline y10 & Dummy variable for 2010 . & \\
\hline shift_up_y10 & $=$ shift_up $\times$ y10. & Own computation \\
\hline shift_down_y10 & $=$ shift_down $\times$ y10. & Own computation \\
\hline lang & $\begin{array}{l}\text { Dummy variable for when two countries } \\
\text { share the same or similar language. }\end{array}$ & $\begin{array}{l}\text { Own computation us- } \\
\text { ing Lewis et al. (2013) } \\
\text { data. }\end{array}$ \\
\hline $\begin{array}{l}\text { ln_wh_gap, } \\
\text { ln_wl_gap }\end{array}$ & $\begin{array}{l}\text { The natural logarithm of imputed wages for } \\
\text { skilled and unskilled. }\end{array}$ & $\begin{array}{l}\text { Own computation us- } \\
\text { ing Solt (2014), Feen- } \\
\text { stra et al. (2013) and } \\
\text { Barro and Lee (2013) } \\
\text { data. }\end{array}$ \\
\hline $\mathrm{pc}_{1}, \mathrm{pc}_{2}, \mathrm{pc}_{3}$ & $\begin{array}{l}\text { Principal components that describe cultural } \\
\text { and historic proximity between a destination } \\
\text { and origin country. }\end{array}$ & $\begin{array}{l}\text { Own computation us- } \\
\text { ing Head et al. (2010) } \\
\text { data. }\end{array}$ \\
\hline ln_dist & $\begin{array}{l}\text { The natural logarithms of physical distance } \\
\text { (in } \mathrm{km} \text { ) between a destination and origin } \\
\text { country. }\end{array}$ & $\begin{array}{l}\text { Mayer and Zignago } \\
(2011)\end{array}$ \\
\hline ln_wgap & $\begin{array}{l}\text { the ratio of the logarithms of GDP per capita } \\
\text { (destination) to the GDP per capita (origin). }\end{array}$ & Feenstra et al. (2013) \\
\hline 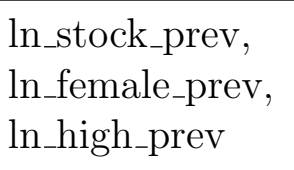 & $\begin{array}{l}\text { The stocks of total, female, and skilled mi- } \\
\text { grants, respectively, in } 1995 \text { and } 2005 \text { divided } \\
\text { by destination country population. }\end{array}$ & $\begin{array}{l}\text { UN (2013), Brücker } \\
\text { et al. (2013) }\end{array}$ \\
\hline ln_stock & $\begin{array}{l}\text { The stock of migrants divided by destination } \\
\text { plus origin county population. }\end{array}$ & UN (2013) \\
\hline female_share & The share of females in total stock. & $\mathrm{UN}(2013)$ \\
\hline skilled_share & The share of skilled in total stock. & Brücker et al. (2013) \\
\hline
\end{tabular}


Table B.3: Examples of county pairs in each visa category in 2010.

Visa required:

USA $\leftarrow$ (MEX, CHN, IND, KOR, VNM, JAM, DOM),

EEA $\leftarrow(T U R$, RUS, KAZ, MKD, MAR, DZA, TUN),

BRA $\leftarrow(J P N$, USA, CHN, LBN, EGY, MEX, CUB),

$\mathrm{ARG} \leftarrow(\mathrm{CHN}, \mathrm{UKR}, \mathrm{CUB}, \mathrm{SYR}, \mathrm{LBN}, \mathrm{ARM}, \mathrm{LAO}, \mathrm{MAR}, \mathrm{IRN})$,

ARG $\leftarrow(\mathrm{DZA}, \mathrm{IND}, \mathrm{IDN}, \mathrm{SAU}, \mathrm{PHL}, \mathrm{NGA}, \mathrm{COG}, \mathrm{ETH}, \mathrm{TZA})$,

$\mathrm{ZAF} \leftarrow(\mathrm{SLB}, \mathrm{TCD}, \mathrm{GMB}, \mathrm{TGO}, \mathrm{BTN}, \mathrm{SLV}, \mathrm{KAZ}, \mathrm{QAT}, \mathrm{DJI}, \mathrm{SUR})$,

$\mathrm{ISR} \leftarrow(\mathrm{MAR}, \mathrm{UKR}, \mathrm{ETH}, \mathrm{IRQ}, \mathrm{VEN}, \mathrm{DZA}, \mathrm{YEM}, \mathrm{TUR}, \mathrm{ZMB}, \mathrm{NRU})$,

KOR $\leftarrow$ (CHN, VNM, PHL, IDN, MNG, UZB, LKA, BGD, NPL),

AUS $\leftarrow(\mathrm{CHN}$, IND, VNM, PHL, ZAF, LBN, IDN, HRV, THA $)$,

$\mathrm{ARE} \leftarrow(\mathrm{IND}, \mathrm{BGD}, \mathrm{PAK}, \mathrm{PHL}), \mathrm{IND}-(\mathrm{BGD}, \mathrm{PAK})$,

$\mathrm{JPN} \leftarrow \mathrm{THA}, \mathrm{CAN} \leftarrow(\mathrm{ZAF}, \mathrm{MAR}, \mathrm{EGY})$,

$\mathrm{GAB} \leftarrow(\mathrm{BEN}, \mathrm{CMR})$.

Visa partially required:

EEA $\leftarrow$ (USA, CAN, BRA, KOR, ISR),

EEA $\leftarrow($ MEX, AUS, NZL, CHL, MYS, VEN),

$\mathrm{USA} \leftarrow($ most EEA $) ; \mathrm{AUS} \leftarrow$ (most EEA $)$

MYS $\leftarrow(I D N$, BGD, NZL, IRQ, GTM, LBN),

$\mathrm{ZAF} \leftarrow(\mathrm{MOZ}, \mathrm{ZWE}, \mathrm{LSO}, \mathrm{GBR}, \mathrm{NAM}, \mathrm{SWZ}, \mathrm{MLW}, \mathrm{ZWE})$,

ARG $\leftarrow$ BRA, most EEA, RUS, COL, MEX, TUR, ISR, PAN, ZAF),

CHL $\leftarrow$ (PER, ARG, BOL, ECU, COL, USA, most EEA, TUR).

Visa not required:

$\mathrm{USA} \leftrightarrow \mathrm{CAN}, \mathrm{AUS} \leftrightarrow \mathrm{NZL}$,

migration within the EEA,

migration within most of the former Soviet Union,

migration between (Bahrain, Kuwait, Oman,

Qatar, Saudi Arabia, and United Arab Emirates),

IND $\leftarrow(N P L, B T N)$; between (DZA-MAR-TUN),

$\mathrm{LBR} \leftarrow(\mathrm{NER}, \mathrm{BFA}, \mathrm{CIV}, \mathrm{GNB}, \mathrm{TGO}, \mathrm{SEN})$,

between (UGA, ERI, KEN).

Note: CZE $\leftarrow$ UKR means migration to the Czech Republic from Ukraine.

Table B.4: Examples of county pairs by allowed durations of visa free stay as of 2010.

Duration of Example of country pairs

visa free stay

\begin{tabular}{|c|c|}
\hline$[3,30)$ days & $\mathrm{MYS} \leftarrow \mathrm{CHN}, \mathrm{VNM} \leftarrow \mathrm{BRN}, \mathrm{DMA} \leftarrow \mathrm{CUB}, \mathrm{LSO} \leftarrow \mathrm{ZWE}, \mathrm{BTN} \leftarrow \mathrm{IND}$. \\
\hline 30 and 31 days & $\mathrm{EGY} \leftarrow(\mathrm{ARG}, \mathrm{AUS}), \mathrm{ARE} \leftarrow \mathrm{AUS}, \mathrm{IDN} \leftarrow \mathrm{CHN}$ \\
\hline$[45,90]$ days & $\begin{array}{l}\mathrm{EU} \leftarrow(\mathrm{AND}, \mathrm{ARG}, \mathrm{AUS}, \mathrm{BRA}, \mathrm{BRB}, \mathrm{USA}, \mathrm{CAN}),(\mathrm{ISR}, \mathrm{TUR}) \leftarrow \mathrm{EU}, \\
\mathrm{URY} \leftarrow \mathrm{CHL}, \mathrm{ZAF} \leftarrow \mathrm{ZWE} .\end{array}$ \\
\hline$[120,365]$ & $\begin{array}{l}\mathrm{CAN} \leftarrow(\mathrm{AUS}, \mathrm{BEL}, \mathrm{BRB}), \mathrm{MEX} \leftarrow(\text { most } \mathrm{EU}, \mathrm{CHL}), \mathrm{GBR} \leftarrow(\mathrm{ISR}, \\
\mathrm{MUS}), \mathrm{GEO} \leftarrow(\text { most countries }) .\end{array}$ \\
\hline
\end{tabular}


Table B.5: Estimates by visa category.

\begin{tabular}{|c|c|c|c|}
\hline Var. name & $\begin{array}{l}v p_{0}=1 \\
\text { Spec. } 1\end{array}$ & $\begin{array}{l}v p_{2}=1 \\
\text { Spec. } 2\end{array}$ & $\begin{array}{l}v p_{2}=1 \\
\text { Spec. } 3\end{array}$ \\
\hline ln_dist & $\begin{array}{l}-0.256^{* * *} \\
(0.02)\end{array}$ & $\begin{array}{l}-0.062^{* * *} \\
(0.02)\end{array}$ & $\begin{array}{l}-0.052 \\
(0.04)\end{array}$ \\
\hline ln_wgap & $\begin{array}{l}0.105 \\
(0.07)\end{array}$ & $\begin{array}{c}-0.083 \\
(0.13)\end{array}$ & $\begin{array}{l}1.766^{* * *} \\
(0.36)\end{array}$ \\
\hline ln_stock_prev & $\begin{array}{l}0.935^{* * * *} \\
(0.01)\end{array}$ & $\begin{array}{l}0.952^{* * * *} \\
(0.01)\end{array}$ & $\begin{array}{l}0.836^{* * *} \\
(0.02)\end{array}$ \\
\hline lang & $\begin{array}{l}0.092^{* *} \\
(0.04)\end{array}$ & $\begin{array}{l}0.003 \\
(0.05)\end{array}$ & $\begin{array}{l}0.197^{* *} \\
(0.08)\end{array}$ \\
\hline $\mathrm{pc}_{1}$ & $\begin{array}{c}-0.011 \\
(0.01)\end{array}$ & $\begin{array}{l}0.001 \\
(0.01)\end{array}$ & $\begin{array}{l}-0.021 \\
(0.02)\end{array}$ \\
\hline $\mathrm{pc}_{2}$ & $\begin{array}{l}0.022 \\
(0.02)\end{array}$ & $\begin{array}{l}0.064^{* * *} \\
(0.01)\end{array}$ & $\begin{array}{l}0.082^{* * *} \\
(0.02)\end{array}$ \\
\hline $\mathrm{pc}_{3}$ & $\begin{array}{l}0.033^{*} \\
(0.02)\end{array}$ & $\begin{array}{l}0.074^{* * * *} \\
(0.02)\end{array}$ & $\begin{array}{l}0.054^{* *} \\
(0.03)\end{array}$ \\
\hline cons & $\begin{array}{l}1.319 \\
(1.27)\end{array}$ & $\begin{array}{c}-1.419 \\
(1.62)\end{array}$ & $\begin{array}{l}-1.640 \\
(3.26)\end{array}$ \\
\hline $\begin{array}{l}\text { Obs. } \\
\text { Adj. } R^{2}\end{array}$ & $\begin{array}{l}10672 \\
0.859\end{array}$ & $\begin{array}{l}6555 \\
0.836\end{array}$ & $\begin{array}{l}1434 \\
0.838\end{array}$ \\
\hline
\end{tabular}

Notes: The dependent variable is $\ln \left(\right.$ stock $\left._{i j t}\right)$. Specifications 1, 2, and 3 are estimated on the subsamples of country pairs with visa required, visa partially required, and visa not required regimes, respectively. All specifications include group specific means of variables. Robust standard errors are in parentheses. ${ }^{*} \mathrm{p}<0.1$, ** $\mathrm{p}<0.05, * * * \mathrm{p}<0.01$. 
Table B.6: The estimates of the female share on the set of covariates.

\begin{tabular}{|c|c|c|c|c|}
\hline Variable name & $\begin{array}{l}\text { OLS } \\
\text { Spec. } 1\end{array}$ & $\begin{array}{l}\text { Robust Reg. } \\
\text { Spec. } 2\end{array}$ & $\begin{array}{l}\text { OLS } \\
\text { Spec. } 3\end{array}$ & $\begin{array}{l}\text { Robust Reg. } \\
\text { Spec. } 4\end{array}$ \\
\hline$v p_{0}$ & \multicolumn{4}{|c|}{ base category } \\
\hline$v p_{1}$ & $\begin{array}{l}-0.001 \\
(0.00)\end{array}$ & $\begin{array}{l}-0.001^{* *} \\
(0.00)\end{array}$ & $\begin{array}{l}0.001 \\
(0.00)\end{array}$ & $\begin{array}{l}-0.002^{* * *} \\
(0.00)\end{array}$ \\
\hline$v p_{2}$ & $\begin{array}{l}-0.012^{* * *} \\
(0.00)\end{array}$ & $\begin{array}{l}-0.006^{* * *} \\
(0.00)\end{array}$ & $\begin{array}{l}-0.009^{* * *} \\
(0.00)\end{array}$ & $\begin{array}{l}-0.007^{* * *} \\
(0.00)\end{array}$ \\
\hline ln_dist & $\begin{array}{l}0.003^{* *} \\
(0.00)\end{array}$ & $\begin{array}{l}0.002^{* * *} \\
(0.00)\end{array}$ & $\begin{array}{l}0.003^{* * *} \\
(0.00)\end{array}$ & $\begin{array}{l}0.003^{* * *} \\
(0.00)\end{array}$ \\
\hline ln_wgap & $\begin{array}{c}-0.032 \\
(0.02)\end{array}$ & $\begin{array}{c}-0.006 \\
(0.01)\end{array}$ & $\begin{array}{l}0.015^{* *} \\
(0.01)\end{array}$ & $\begin{array}{l}0.007^{* * *} \\
(0.00)\end{array}$ \\
\hline fratio_prev & $\begin{array}{l}0.704^{* * *} \\
(0.01)\end{array}$ & $\begin{array}{l}0.983^{* * *} \\
(0.00)\end{array}$ & $\begin{array}{l}0.710^{* * *} \\
(0.01)\end{array}$ & $\begin{array}{l}0.983^{* * *} \\
(0.00)\end{array}$ \\
\hline ln_female_prev & $\begin{array}{l}0.000 \\
(0.00)\end{array}$ & $\begin{array}{l}0.001^{* * *} \\
(0.00)\end{array}$ & $\begin{array}{l}0.001^{*} \\
(0.00)\end{array}$ & $\begin{array}{l}0.001^{* * *} \\
(0.00)\end{array}$ \\
\hline lang & $\begin{array}{l}0.006^{* *} \\
(0.00)\end{array}$ & $\begin{array}{l}0.000 \\
(0.00)\end{array}$ & $\begin{array}{l}0.002 \\
(0.00)\end{array}$ & $\begin{array}{l}-0.001 \\
(0.00)\end{array}$ \\
\hline $\mathrm{pc}_{1}$ & $\begin{array}{l}0.001 * \\
(0.00)\end{array}$ & $\begin{array}{l}0.000 \\
(0.00)\end{array}$ & $\begin{array}{l}0.000 \\
(0.00)\end{array}$ & $\begin{array}{l}0.000 \\
(0.00)\end{array}$ \\
\hline $\mathrm{pc}_{2}$ & $\begin{array}{l}0.002^{* * *} \\
(0.00)\end{array}$ & $\begin{array}{l}0.000 \\
(0.00)\end{array}$ & $\begin{array}{l}0.002^{* * *} \\
(0.00)\end{array}$ & $\begin{array}{l}-0.000 \\
(0.00)\end{array}$ \\
\hline $\mathrm{pc}_{3}$ & $\begin{array}{l}-0.001 \\
(0.00)\end{array}$ & $\begin{array}{l}-0.000 \\
(0.00)\end{array}$ & $\begin{array}{l}-0.001 \\
(0.00)\end{array}$ & $\begin{array}{l}-0.001^{*} \\
(0.00)\end{array}$ \\
\hline cons & $\begin{array}{l}0.16^{* * *} \\
(0.04)\end{array}$ & $\begin{array}{l}-0.016 \\
(0.02)\end{array}$ & $\begin{array}{l}-0.62^{* * *} \\
(0.1)\end{array}$ & $\begin{array}{l}-0.363^{* * *} \\
(0.03)\end{array}$ \\
\hline Adj. $R^{2}$ & 0.681 & 0.979 & 0.663 & 0.972 \\
\hline
\end{tabular}

Notes: The dependent variable is the share of females in stocks. Spec. 1 and 2 include destination, origin, and year dummies. Spec. 3 and 4 contain the group means of the variables. The number of observations is 18661 in each equation. Robust standard errors are in parentheses. ${ }^{*} \mathrm{p}<0.1,{ }^{* *} \mathrm{p}<0.05,{ }^{* * *} \mathrm{p}<0.01$. 
Table B.7: The estimates of the share of skilled migrants on the set of covariates.

\begin{tabular}{|c|c|c|c|c|c|}
\hline & $\begin{array}{l}\text { OLS } \\
\text { Spec. } 1\end{array}$ & $\begin{array}{l}\text { Rob. Reg } \\
\text { Spec. } 2\end{array}$ & $\begin{array}{l}\text { OLS } \\
\text { Spec. } 3\end{array}$ & $\begin{array}{l}\text { Rob Reg. } \\
\text { Spec. } 4\end{array}$ & $\begin{array}{l}\text { LAD } \\
\text { Spec. } 5\end{array}$ \\
\hline$v p_{0}$ & \multicolumn{5}{|c|}{ base category } \\
\hline$v p_{1}$ & $\begin{array}{l}0.003 \\
(0.00)\end{array}$ & $\begin{array}{l}-0.003 \\
(0.00)\end{array}$ & $\begin{array}{l}0.002 \\
(0.01)\end{array}$ & $\begin{array}{l}-0.003 \\
(0.00)\end{array}$ & $\begin{array}{l}-0.005 \\
(0.00)\end{array}$ \\
\hline$v p_{2}$ & $\begin{array}{l}0.010 \\
(0.01)\end{array}$ & $\begin{array}{l}-0.015^{* * *} \\
(0.00)\end{array}$ & $\begin{array}{l}0.010 \\
(0.01)\end{array}$ & $\begin{array}{l}-0.013^{\text {*** }} \\
(0.00)\end{array}$ & $\begin{array}{l}-0.018^{* * *} \\
(0.00)\end{array}$ \\
\hline ln_dist & $\begin{array}{l}-0.004^{*} \\
(0.00)\end{array}$ & $\begin{array}{l}-0.006^{* * *} \\
(0.00)\end{array}$ & $\begin{array}{l}-0.003 \\
(0.00)\end{array}$ & $\begin{array}{l}-0.005^{\text {*** }} \\
(0.00)\end{array}$ & $\begin{array}{l}-0.004^{* *} \\
(0.00)\end{array}$ \\
\hline ln_high_prev & $\begin{array}{l}-0.013^{\text {*** }} \\
(0.00)\end{array}$ & $\begin{array}{l}-0.004^{* * *} \\
(0.00)\end{array}$ & $\begin{array}{l}-0.010^{\text {*** }} \\
(0.00)\end{array}$ & $\begin{array}{l}-0.004^{\text {*** }} \\
(0.00)\end{array}$ & $\begin{array}{l}-0.005^{* * *} \\
(0.00)\end{array}$ \\
\hline share_high_prev & $\begin{array}{l}0.757^{* * *} \\
(0.02)\end{array}$ & $\begin{array}{l}0.954^{* * *} \\
(0.00)\end{array}$ & $\begin{array}{l}0.755^{* * *} \\
(0.02)\end{array}$ & $\begin{array}{l}0.932^{* * *} \\
(0.01)\end{array}$ & $\begin{array}{l}0.918^{* * *} \\
(0.01)\end{array}$ \\
\hline ln_wh_gap & $\begin{array}{l}-0.003 \\
(0.01)\end{array}$ & $\begin{array}{l}0.006 \\
(0.00)\end{array}$ & $\begin{array}{l}0.000 \\
(0.00)\end{array}$ & $\begin{array}{l}0.002^{*} \\
(0.00)\end{array}$ & $\begin{array}{l}0.002 \\
(0.00)\end{array}$ \\
\hline ln_wl_gap & $\begin{array}{l}-0.002 \\
(0.00)\end{array}$ & $\begin{array}{l}-0.002 \\
(0.00)\end{array}$ & $\begin{array}{l}-0.003^{*} \\
(0.00)\end{array}$ & $\begin{array}{l}-0.003^{* *} \\
(0.00)\end{array}$ & $\begin{array}{l}-0.002^{* *} \\
(0.00)\end{array}$ \\
\hline lang & $\begin{array}{l}0.016^{* * *} \\
(0.00)\end{array}$ & $\begin{array}{l}0.005^{* *} \\
(0.00)\end{array}$ & $\begin{array}{l}0.012^{* * *} \\
(0.00)\end{array}$ & $\begin{array}{l}0.002 \\
(0.00)\end{array}$ & $\begin{array}{l}0.002 \\
(0.00)\end{array}$ \\
\hline $\mathrm{pc}_{1}$ & $\begin{array}{l}0.000 \\
(0.00)\end{array}$ & $\begin{array}{l}0.000 \\
(0.00)\end{array}$ & $\begin{array}{l}-0.001 \\
(0.00)\end{array}$ & $\begin{array}{l}0.000 \\
(0.00)\end{array}$ & $\begin{array}{l}0.001^{*} \\
(0.00)\end{array}$ \\
\hline $\mathrm{pc}_{2}$ & $\begin{array}{l}-0.001^{*} \\
(0.00)\end{array}$ & $\begin{array}{l}-0.000 \\
(0.00)\end{array}$ & $\begin{array}{l}-0.001^{*} \\
(0.00)\end{array}$ & $\begin{array}{l}-0.001 \\
(0.00)\end{array}$ & $\begin{array}{l}-0.000 \\
(0.00)\end{array}$ \\
\hline $\mathrm{pc}_{3}$ & $\begin{array}{l}0.002^{*} \\
(0.00)\end{array}$ & $\begin{array}{l}-0.000 \\
(0.00)\end{array}$ & $\begin{array}{l}0.002^{* *} \\
(0.00)\end{array}$ & $\begin{array}{l}-0.000 \\
(0.00)\end{array}$ & $\begin{array}{l}-0.000 \\
(0.00)\end{array}$ \\
\hline cons & $\begin{array}{l}-0.058 \\
(0.04)\end{array}$ & $\begin{array}{l}-0.030 \\
(0.02)\end{array}$ & $\begin{array}{l}0.356^{* * *} \\
(0.13)\end{array}$ & $\begin{array}{l}-0.067 \\
(0.07)\end{array}$ & $\begin{array}{l}-0.248^{* * *} \\
(0.08)\end{array}$ \\
\hline Adj. $R^{2}$ & 0.854 & 0.962 & 0.842 & 0.944 & 0.83 \\
\hline
\end{tabular}

Notes: The dependent variable is the share of skilled migrants in stocks. Spec. 1 and 2 include destination, origin, and year dummies. Spec. $3-5$ have the group means of the variables. In spec. $5 R^{2}$ is computed as the square of the correlation coefficient. The number of observations is 4747 in each equation. Robust standard errors are in parentheses. ${ }^{*} \mathrm{p}<0.1$, $* * \mathrm{p}<0.05,{ }^{* * *} \mathrm{p}<0.01$. 


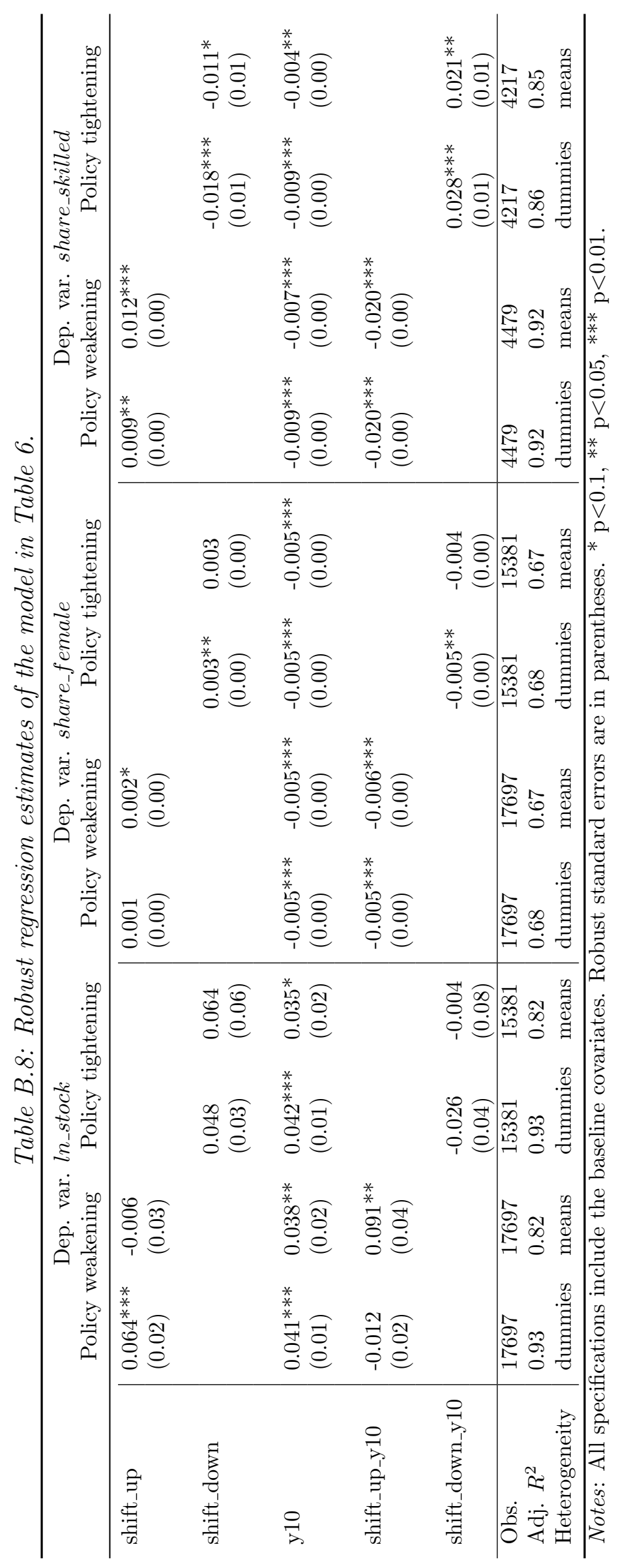


Table B.9: Policy changes 2000-2010. A dot means no change.

\begin{tabular}{|c|c|c|c|c|}
\hline Country & ISO code & $\mathrm{d}(\mathrm{i}, \mathrm{vp}=0)$ & $\mathrm{d}(\mathrm{i}, \mathrm{vp}=1)$ & $d(i, v p=2)$ \\
\hline Jamaica & JAM & -0.01 & -0.21 & 0.22 \\
\hline Andorra & AND & -0.33 & 0.17 & 0.15 \\
\hline Holy See & VAT & -0.05 & -0.10 & 0.15 \\
\hline San Marino & SMR & -0.05 & -0.10 & 0.15 \\
\hline Latvia & LVA & -0.08 & -0.06 & 0.15 \\
\hline Lithuania & LTU & -0.15 & & 0.15 \\
\hline Cyprus & CYP & 0.07 & -0.22 & 0.15 \\
\hline Belgium & BEL & -0.05 & -0.09 & 0.15 \\
\hline Estonia & $\mathrm{EST}$ & -0.13 & -0.02 & 0.15 \\
\hline Romania & $\mathrm{ROU}$ & -0.21 & 0.06 & 0.15 \\
\hline Poland & POL & -0.11 & -0.04 & 0.15 \\
\hline Italy & ITA & -0.05 & -0.09 & 0.15 \\
\hline Hungary & HUN & -0.03 & -0.11 & 0.15 \\
\hline Malta & MLT & 0.28 & -0.43 & 0.15 \\
\hline Slovenia & SVN & -0.08 & -0.07 & 0.15 \\
\hline Iceland & ISL & -0.01 & -0.14 & 0.15 \\
\hline Switzerland & $\overline{\mathrm{CHE}}$ & 0.05 & -0.20 & 0.14 \\
\hline Czech Republic & $\mathrm{CZE}$ & -0.11 & -0.03 & 0.14 \\
\hline Liechtenstein & LIE & 0.05 & -0.20 & 0.14 \\
\hline Slovakia & SVK & -0.11 & -0.03 & 0.14 \\
\hline Guinea & GIN & 0.00 & -0.10 & 0.10 \\
\hline Trinidad and Tobago & TTO & -0.18 & 0.08 & 0.10 \\
\hline United Kingdom & GBR & -0.01 & -0.06 & 0.07 \\
\hline Monaco & $\mathrm{MCO}$ & -0.10 & 0.03 & 0.07 \\
\hline Greece & GRC & -0.08 & 0.01 & 0.07 \\
\hline Germany & DEU & -0.03 & -0.03 & 0.07 \\
\hline Sweden & SWE & 0.05 & -0.12 & 0.07 \\
\hline Ireland & IRL & -0.08 & 0.01 & 0.07 \\
\hline Denmark & DNK & -0.04 & -0.03 & 0.07 \\
\hline Austria & AUT & -0.05 & -0.01 & 0.07 \\
\hline Luxembourg & LUX & -0.05 & -0.02 & 0.07 \\
\hline Norway & NOR & 0.06 & -0.13 & 0.07 \\
\hline Spain & ESP & -0.05 & -0.02 & 0.07 \\
\hline Finland & FIN & 0.02 & -0.09 & 0.07 \\
\hline France & FRA & -0.10 & 0.03 & 0.07 \\
\hline Portugal & PRT & -0.10 & 0.03 & 0.07 \\
\hline Netherlands & NLD & -0.05 & -0.01 & 0.06 \\
\hline Tunisia & TUN & 0.02 & -0.04 & 0.02 \\
\hline Northern Mariana Islands & MNP & 0.83 & -0.85 & 0.02 \\
\hline Kyrgyzstan & KGZ & -0.15 & 0.13 & 0.01 \\
\hline Liberia & LBR & -0.01 & . & 0.01 \\
\hline Eritrea & ERI & -0.01 & ${ }^{\circ}$ & 0.01 \\
\hline Marshall Islands & MHL & -0.20 & 0.19 & 0.01 \\
\hline Angola & $\mathrm{AGO}$ & -0.01 & & 0.01 \\
\hline Micronesia (Federated States of) & FSM &. & -0.01 & 0.01 \\
\hline India & IND & & -0.01 & 0.01 \\
\hline Ethiopia & ETH & -0.18 & 0.17 & 0.00 \\
\hline Burundi & BDI & -0.01 & 0.00 & 0.00 \\
\hline American Samoa & ASM & 0.84 & -0.85 & 0.00 \\
\hline Jordan & JOR & -0.03 & 0.03 & . \\
\hline Chile & CHL & -0.06 & 0.06 & . \\
\hline The former Yugoslav Republic of Macedonia & MKD & -0.05 & 0.05 & . \\
\hline Barbados & BRB & 0.01 & -0.01 & . \\
\hline Grenada & GRD & -0.02 & 0.02 & . \\
\hline Bahrain & $\mathrm{BHR}$ & -0.07 & 0.07 & . \\
\hline Croatia & $\mathrm{HRV}$ & -0.11 & 0.11 & . \\
\hline Saudi Arabia & SAU & & & \\
\hline Zambia & ZMB & 0.03 & -0.03 & $\dot{.}$ \\
\hline Albania & ALB & -0.10 & 0.10 & . \\
\hline Zimbabwe & ZWE & 0.25 & -0.25 & . \\
\hline Bermuda & $\mathrm{BMU}$ & -0.73 & 0.73 & . \\
\hline Lebanon & LBN & -0.37 & 0.37 & . \\
\hline Malawi & MWI & -0.04 & 0.04 & . \\
\hline Bosnia and Herzegovina & $\mathrm{BIH}$ & -0.12 & 0.12 & . \\
\hline Namibia & NAM & -0.07 & 0.07 & . \\
\hline Cuba & CUB & -0.01 & 0.01 & . \\
\hline \multirow[t]{2}{*}{ Honduras } & HND & -0.22 & 0.22 &. \\
\hline & & & continued on & next page \\
\hline
\end{tabular}


Table B.9 - continued from previous page

\begin{tabular}{|c|c|c|c|c|}
\hline Country name & ISO code & $\mathrm{d}(\mathrm{i}, \mathrm{vp}=0)$ & $\mathrm{d}(\mathrm{i}, \mathrm{vp}=1)$ & $\mathrm{d}(\mathrm{i}, \mathrm{vp}=2)$ \\
\hline Somalia & SOM & 0.00 & 0.00 & . \\
\hline Paraguay & PRY & -0.13 & 0.13 & . \\
\hline Aruba & ABW & -0.24 & 0.24 & $\dot{.}$ \\
\hline Iraq & IRQ & -0.15 & 0.15 & . \\
\hline Bolivia (Plurinational State of) & $\mathrm{BOL}$ & -0.14 & 0.14 & . \\
\hline United States Virgin Islands & VIR & 0.00 & 0.00 & . \\
\hline Burkina Faso & BFA & 0.19 & -0.19 & . \\
\hline Mali & MLI & -0.90 & 0.90 & \\
\hline Tuvalu & TUV & -0.57 & 0.57 & $\dot{.}$ \\
\hline Uganda & UGA & -1.00 & 1.00 & $\dot{.}$ \\
\hline Togo & TGO & & & \\
\hline Côte d'Ivoire & CIV & 0.01 & -0.01 & . \\
\hline Seychelles & SYC & 0.00 & 0.00 & . \\
\hline New Zealand & NZL & -0.10 & 0.10 &. \\
\hline Indonesia & IDN & -0.14 & 0.14 & . \\
\hline Equatorial Guinea & GNQ & & & . \\
\hline Colombia & $\mathrm{COL}$ & -0.28 & 0.28 & . \\
\hline Mauritius & MUS & -0.18 & 0.18 & . \\
\hline Bangladesh & BGD & -0.73 & 0.73 & . \\
\hline Republic of Korea & KOR & -0.28 & 0.28 & . \\
\hline Lao People's Democratic Republic & $\mathrm{LAO}$ & -0.05 & 0.05 & . \\
\hline Iran (Islamic Republic of) & IRN & 0.00 & 0.00 & . \\
\hline Guatemala & GTM & -0.25 & 0.25 & . \\
\hline Mauritania & MRT & 0.01 & -0.01 & . \\
\hline Madagascar & MDG & & & . \\
\hline Kuwait & KWT & -0.19 & 0.19 & . \\
\hline China, Hong Kong Special Administrative Region & HKG & 0.01 & -0.01 & . \\
\hline United Arab Emirates & ARE & -0.16 & 0.16 & . \\
\hline Gabon & $\mathrm{GAB}$ & 0.03 & -0.03 & . \\
\hline Peru & PER & -0.08 & 0.08 & . \\
\hline Chad & TCD & & & $\dot{.}$ \\
\hline Dominica & DMA & -0.87 & 0.87 & . \\
\hline French Guiana & GUF & -0.09 & 0.09 & . \\
\hline Kiribati & KIR & -0.11 & 0.11 & . \\
\hline Oman & OMN & -0.33 & 0.33 & . \\
\hline Serbia & SRB & -0.17 & 0.17 & . \\
\hline Thailand & THA & -0.05 & 0.05 & . \\
\hline Malavsia & MYS & 0.01 & -0.01 &. \\
\hline French Polynesia & PYF & -0.09 & 0.09 & $\dot{.}$ \\
\hline Djibouti & DJI & -0.90 & 0.90 & . \\
\hline Cape Verde & CPV & -0.01 & 0.01 & . \\
\hline Argentina & ARG & -0.12 & 0.12 & $\dot{.}$ \\
\hline Senegal & SEN & & & $\dot{.}$ \\
\hline Nicaragua & NIC & -0.89 & 0.89 & . \\
\hline Réunion & REU & -0.08 & 0.08 & $\dot{.}$ \\
\hline Fiji & FJI & -0.10 & 0.10 & . \\
\hline Saint Vincent and the Grenadines & VCT & 0.04 & -0.04 & . \\
\hline Cambodia & KHM & . &. & . \\
\hline Samoa & WSM & & & . \\
\hline Nigeria & NGA & 0.00 & 0.00 & . \\
\hline Niue & NIU & 0.85 & -0.85 & . \\
\hline Australia & AUS & -0.10 & 0.10 & . \\
\hline Philippines & PHL & 0.03 & -0.03 & . \\
\hline Palau & PLW & & & . \\
\hline El Salvador & SLV & -0.27 & $0 . \dot{2} 7$ & $\dot{.}$ \\
\hline Lesotho & LSO & 0.04 & -0.04 & . \\
\hline Mozambique & MOZ & -1.00 & 1.00 & . \\
\hline Montenegro & MNE & -0.21 & 0.21 & . \\
\hline Bahamas & BHS & -0.09 & 0.09 & . \\
\hline Japan & JPN & -0.05 & 0.05 & . \\
\hline Kenya & KEN & -0.68 & 0.68 & . \\
\hline Papua New Guinea & PNG & 0.41 & -0.41 & $\dot{.}$ \\
\hline United Republic of Tanzania & TZA & -0.47 & 0.47 & . \\
\hline Mexico & MEX & -0.11 & 0.11 & . \\
\hline Maldives & MDV & & & \\
\hline Benin & $\mathrm{BEN}$ & 0.00 & 0.00 & . \\
\hline Mavotte & MYT & -0.09 & 0.09 & . \\
\hline Bhutan & $\mathrm{BTN}$ & 0.00 & 0.00 & . \\
\hline Turkey & TUR & -0.06 & 0.06 & 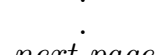 \\
\hline
\end{tabular}


Table B.9 - continued from previous page

\begin{tabular}{|c|c|c|c|c|}
\hline Country name & ISO code & $\mathrm{d}(\mathrm{i}, \mathrm{vp}=0)$ & $\mathrm{d}(\mathrm{i}, \mathrm{vp}=1)$ & $d(i, v p=2)$ \\
\hline Guadeloupe & GLP & -0.09 & 0.09 & . \\
\hline Sao Tome and Principe & $\mathrm{STP}$ & 1.00 & -1.00 & . \\
\hline Qatar & QAT & -0.16 & 0.16 & $\dot{.}$ \\
\hline Dominican Republic & DOM & -0.18 & 0.18 & . \\
\hline Tonga & TON & 0.63 & -0.63 & $\dot{.}$ \\
\hline Ecuador & $\mathrm{ECU}$ & -0.07 & 0.07 & . \\
\hline Gambia & GMB & 0.00 & 0.00 & . \\
\hline Comoros & COM & & & . \\
\hline Panama & PAN & -0.05 & 0.05 & . \\
\hline Turks and Caicos Islands & TCA & -0.06 & 0.06 & . \\
\hline Morocco & MAR & -0.08 & 0.08 & . \\
\hline Botswana & BWA & -0.17 & 0.17 & . \\
\hline Nauru & NRU & -0.19 & 0.19 & . \\
\hline Saint Kitts and Nevis & KNA & 0.33 & -0.33 & . \\
\hline Viet Nam & VNM & -0.07 & 0.07 & . \\
\hline Brazil & $\mathrm{BRA}$ & -0.11 & 0.11 & . \\
\hline Brunei Darussalam & BRN & -0.14 & 0.14 & $\dot{.}$ \\
\hline Guyana & GUY & -0.02 & 0.02 & . \\
\hline Sri Lanka & LKA & -0.04 & 0.04 & . \\
\hline Algeria & $\mathrm{DZA}$ & 0.03 & -0.03 & . \\
\hline Guam & GUM & -0.03 & 0.03 & . \\
\hline Israel & ISR & -0.09 & 0.09 & . \\
\hline Myanmar & MMR & & & . \\
\hline United States of America & USA & 0.00 & 0.00 & . \\
\hline Nepal & NPL & 0.05 & -0.05 & . \\
\hline Haiti & HTI & -0.87 & 0.87 & . \\
\hline China & $\mathrm{CHN}$ & -0.02 & 0.02 & . \\
\hline Ghana & GHA & 0.01 & -0.01 & . \\
\hline Vanuatu & VUT & -0.06 & 0.06 & . \\
\hline Rwanda & RWA & -0.04 & 0.04 & . \\
\hline New Caledonia & NCL & -0.06 & 0.06 & $\dot{.}$ \\
\hline Puerto Rico & PRI & 0.00 & 0.00 & . \\
\hline Antigua and Barbuda & ATG & 0.02 & -0.02 & . \\
\hline Sierra Leone & SLE & 0.00 & 0.00 & . \\
\hline Egypt & EGY & -0.05 & 0.05 & . \\
\hline Uruguay & URY & -0.09 & 0.09 & . \\
\hline Costa Rica & CRI & -0.08 & 0.08 & . \\
\hline Cook Islands & COK & & & \\
\hline Canada & CAN & 0.02 & -0.02 & . \\
\hline Bulgaria & BGR & -0.08 & 0.08 & . \\
\hline Cameroon & CMR & ond &. & . \\
\hline Pakistan & PAK & 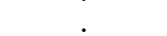 & 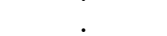 & 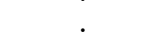 \\
\hline Saint Lucia & $\mathrm{LCA}$ & -0.13 & 0.13 & 0.00 \\
\hline Solomon Islands & SLB & 0.29 & -0.28 & 0.00 \\
\hline Belize & BLZ & -0.08 & 0.09 & 0.00 \\
\hline Venezuela (Bolivarian Republic of) & VEN & -0.13 & 0.13 & 0.00 \\
\hline Syrian Arab Republic & SYR & & 0.00 & 0.00 \\
\hline Ǔkraine & UKR & -0.13 & 0.14 & -0.01 \\
\hline Sudan & SDN & -0.01 & 0.02 & -0.01 \\
\hline Russian Federation & RUS & 0.02 & -0.01 & -0.01 \\
\hline Azerbaijan & AZE & 0.00 & 0.00 & -0.01 \\
\hline Uzbekistan & UZB & 0.01 & 0.00 & -0.01 \\
\hline Mongolia & MNG & -0.01 & 0.03 & -0.02 \\
\hline Singapore & SGP & 0.02 & 0.00 & -0.02 \\
\hline Gibraltar & GIB & 0.03 & & -0.03 \\
\hline Swaziland & SWZ & -0.10 & 0.14 & -0.04 \\
\hline Kazakhstan & KAZ & 0.03 & 0.01 & -0.04 \\
\hline Belarus & BLR & 0.02 & 0.02 & -0.05 \\
\hline Central African Republic & $\mathrm{CAF}$ & 0.06 & . & -0.06 \\
\hline Turkmenistan & TKM & 0.07 & . & -0.07 \\
\hline Libya & LBY & 0.06 & 0.01 & -0.07 \\
\hline Yemen & YEM & -0.13 & 0.22 & -0.09 \\
\hline Suriname & SUR & -0.01 & 0.12 & -0.11 \\
\hline South Africa & ZAF & -0.03 & 0.15 & -0.12 \\
\hline China, Macao Special Administrative Region & MAC & -0.16 & 0.33 & -0.17 \\
\hline Montserrat & MSR & -0.14 & 0.45 & -0.31 \\
\hline Cayman Islands & CYM & 0.00 & 0.43 & -0.44 \\
\hline
\end{tabular}


C Figures 


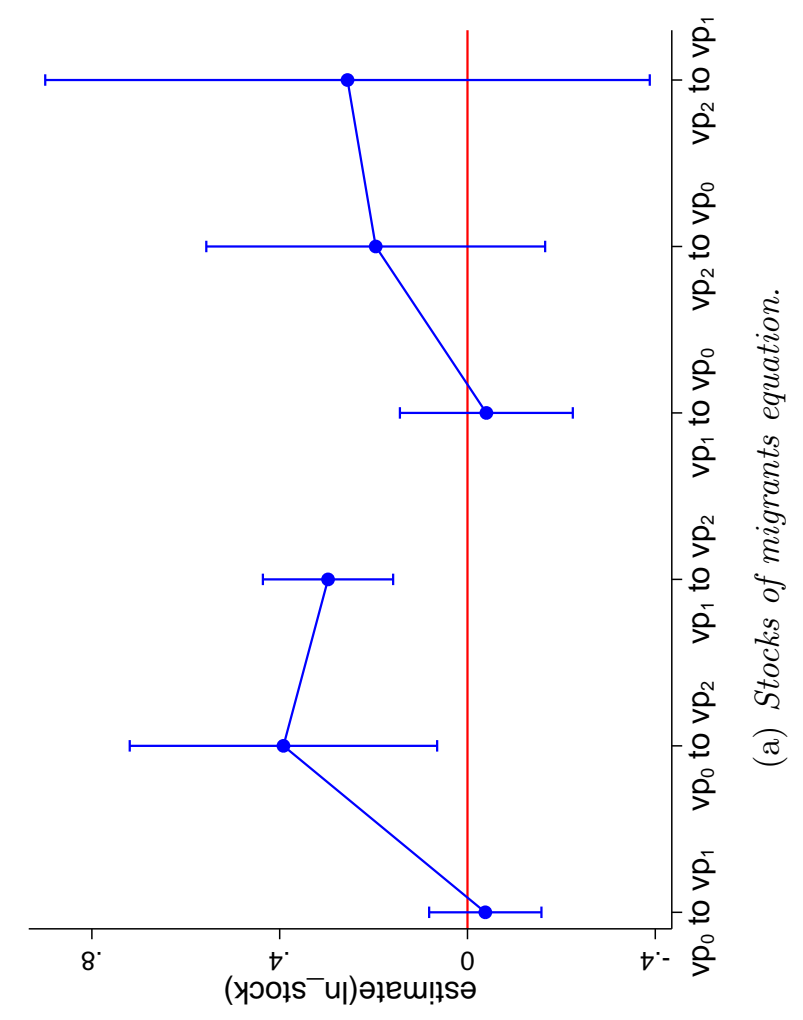




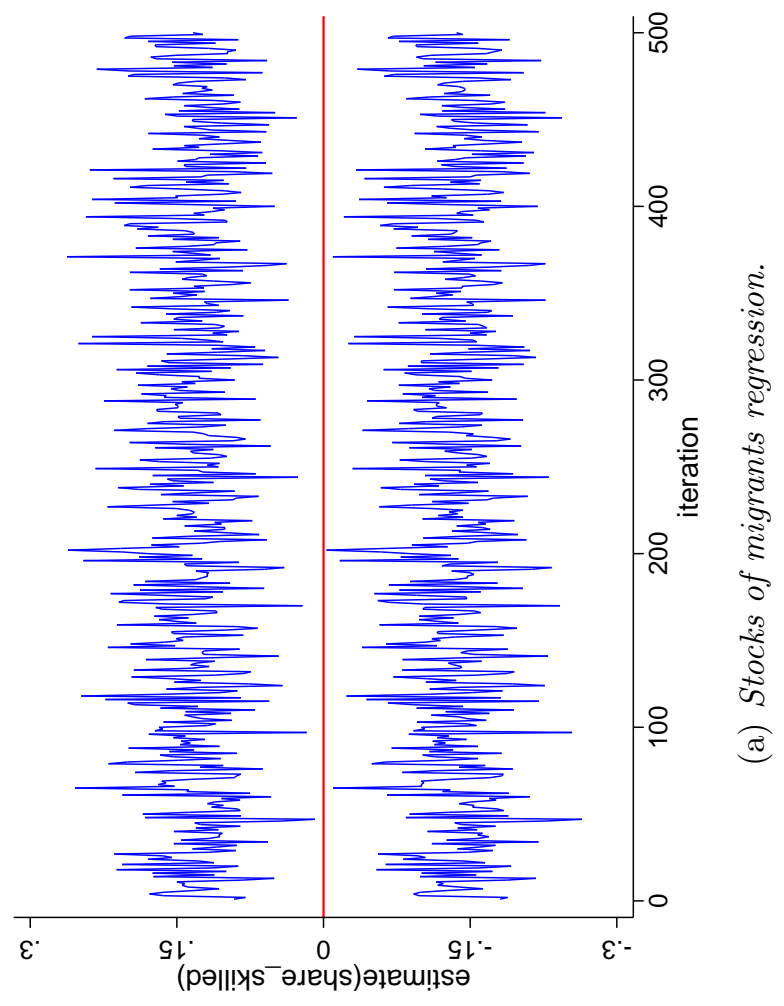




\section{Working Paper Series}

ISSN 1211-3298

Registration No. (Ministry of Culture): E 19443

Individual researchers, as well as the on-line and printed versions of the CERGE-EI Working Papers (including their dissemination) were supported from institutional support RVO 67985998 from Economics Institute of the ASCR, v. v. i.

Specific research support and/or other grants the researchers/publications benefited from are acknowledged at the beginning of the Paper.

(c) Dmytro Vikhrov, 2014

All rights reserved. No part of this publication may be reproduced, stored in a retrieval system or transmitted in any form or by any means, electronic, mechanical or photocopying, recording, or otherwise without the prior permission of the publisher.

Published by

Charles University in Prague, Center for Economic Research and Graduate Education (CERGE) and

Economics Institute of the ASCR, v. v. i. (EI)

CERGE-El, Politických vězňu 7, 11121 Prague 1, tel.: +420 224005 153, Czech Republic.

Printed by CERGE-EI, Prague

Subscription: CERGE-EI homepage: http://www.cerge-ei.cz

Phone: + 420224005153

Email: office@cerge-ei.cz

Web: http://www.cerge-ei.cz

Editor: Marek Kapička

The paper is available online at http://www.cerge-ei.cz/publications/working_papers/.

ISBN 978-80-7343-328-4 (Univerzita Karlova. Centrum pro ekonomický výzkum a doktorské studium)

ISBN 978-80-7344-320-7 (Akademie věd České republiky. Národohospodářský ústav) 
CERGE-EI

P.O.BOX 882

Politických vězňů 7

11121 Praha 1

Czech Republic http://www.cerge-ei.cz 